Studies in African Linguistics

Volume 37, Number 2, 2008

\title{
ON THE ORIGIN OF TONAL CLASSES IN KINANDE NOUN STEMS*
}

\author{
Michael Kenstowicz \\ MIT
}

hommage à G.N. Clements

This paper investigates the Proto-Bantu origins of the principal tonal classes in Kinande nonderived mono- and disyllabic nominal stems. The ternary $\mathrm{H}$ vs. $\mathrm{L}$ vs. 0 distinction in the final syllable of the current language is traced back to a binary $\mathrm{H}$ vs. L contrast in Proto Bantu on the basis of two strata of reconstruction: first, a shallow one based on c. 200 PB cognates shared with the closely related Lacustrine languages Runyankore, Haya, and Jita, and second, a deeper one based on c. 100 PB cognates shared with the more distantly related Congolese languages Tembo, Luba, and Lingala. A chronology of tone changes is postulated in which different sequencing of the same changes as well as alternative phonologizations of ambiguous phonetic structures play a key role.

\section{Introduction.}

In one of the first investigations of the tonology of the Bantu language Kinande (D42), Hyman (1990) isolated the six contrasting tone patterns of (1a) for disyllabic noun stems. ${ }^{1}$ They arise principally from a process shifting a high tone $(\mathrm{H})$ one syllable to the left. In addition, to account for the contrast between the stable

* This paper was written while the author was a Visiting Professor at the Institute for Languages and Cultures of Asia and Africa at the Tokyo University of Foreign Studies, whose support is gratefully acknowledged. A preliminary version was read at the ACAL 40, April 2009, University of Illinois. Thanks to Laura Downing, José Hualde, Larry Hyman, Patrick Jones, as well as two anonymous reviewers whose comments were particularly helpful. Special thanks to our Kinande consultant Pierre Mujomba for sharing his language.

${ }^{\prime}$ There are actually a few additional minor patterns; see section 5. As a representative of the tonal class of e-ki-hánde 'piece of cloth' Hyman (1990) designates e-ki-tábu 'book' a Swahili loan ultimately from Arabic. 
$\mathrm{H}$ of $e$-ki-hánde vs. the alternating $\mathrm{H}$ of e-ki-ryátu, the phrase-medial form appearing before the modifier ki-rito 'heavy' is taken as underlying and a process that attaches $\mathrm{H}-\mathrm{L} \%$ boundary tones to the penultimate and last syllables of the phrase-final form is proposed. Words like e-ki-tsungu and e-ki-koba that block the attachment of the $\mathrm{H}-\mathrm{L} \%$ are assigned an underlying final low tone (L). As seen in (1b), this structure prevents the $\mathrm{H} \%$ from reaching the penult by the ban on crossing autosegmental association lines. Kinande thus presents an underlying ternary /H-L-0/ contrast on the final syllable of disyllabic stems in this analysis.
a. citation
phrase medial
gloss
lexical type
e-ki-ryátu
e-ki-ryatu ki-ríto
shoe
/ryatu/
$100 /$
e-ki-tsungu
e-ki-tsungu ki-ríto
potato
/tsungù/
/0L/
e-kís-rimus
e-kí-rimus kịs-ríto
spirit
/rúmu/
e-kí-koba
e-ḱ́-koba kis-ríto
rope
/kóbà/
e-ki-hánde
e-ki-hánde kị-ríto
e-kí-sáka
e-ḱ́-sáka kị-ríto
cloth
/handé/
$/ \mathrm{HO} /$
branch /sáká/
/HL/
$/ 0 \mathrm{H} /$
/HH/
b. e-ki-ryaty
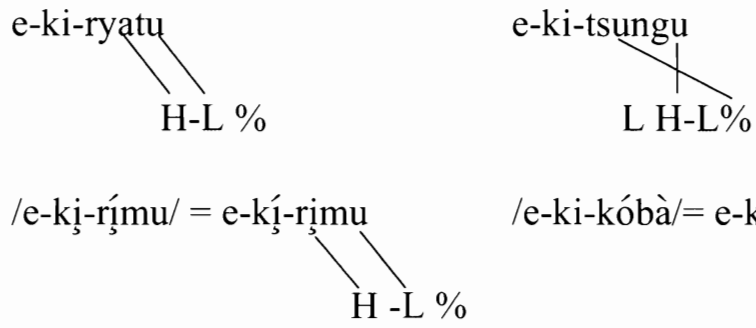
/e-ki-kóbà/= e-kí-koba
L H-L \%

Given that Proto-Bantu (PB) nouns are reconstructed with four contrasting tonal shapes /HH, HL, LH, LL/ by Greenberg (1948) and Guthrie (1967-1971), the question of the diachronic origin of the Kinande stem classes arises. The goal of this paper is to shed light on this matter. The paper has three parts. First, we report the results of an analysis of c. 200 cognates shared between Kinande and several closely related Lacustrine languages based on the material in recently published lexicons of substantial (over 1,000 entries) size for J.31 Runyankore (Kaji 2004), K.12a Haya (Kaji 2000), and E.24, 25 Jita (Downing 1996 Ukewere dialect and Kagaya 2005 Mrangi dialect)-see Appendix A. Second, we explore the origin of the contrast between the final L of /kóbà/ vs. the 0 of /rísmus/ based on the material in the lexicons for the more distantly related Congolese languages D.54 Tembo (Kaji 1986, 1996), L.31 Luba (Yukawa 1992), and C.36 Lingala (Kaji 1992), in order to evaluate the hypothesis of Meeussen (1976) that Kinande 
/HL/ corresponds to PB HH while Kinande /H0/ corresponds to PB HL-see Appendix B. Third, we consider the implications of this result with respect to the presumed chronology of tonal changes that must have occurred in the development of Kinande from Proto-Bantu. Finally, we note various extensions of the /L/ vs. /0/ contrast in the contemporary Kinande lexicon.

\section{Preliminaries.}

In Kinande the attachment of the boundary $\mathrm{H}-\mathrm{L} \%$ to the penultimate and final syllables of the stem neutralizes the contrast with an underlying /HL/ stem. Thus, on the basis of the citation form, one cannot predict if the $\mathrm{H}$ on the penult will disappear (or shift), as in e-ki-ryátu 'shoe', e-ki-ryatu ki-ríto 'heavy shoe', or remain attached to that syllable, as in e-ki-hánde 'cloth', e-ki-hánde ki-ríto 'heavy cloth', as the phrasal context is altered. This surface ambiguity is at the basis of several lexical realignments discussed below. In order to substantiate the assertion that there is no phonetic difference between the two forms, we recorded and analyzed a sample of two repetitions of ten stems each from the two classes with the help of our consultant. No discernible difference in either peak height, alignment, or syllable duration was observed: cf. the normalized F0 contours over the last two syllables (employing a Praat script from Xu 2007) in (2).

$$
\text { Time-Normalized F0 contours of H-L\% vs. HL nouns }
$$

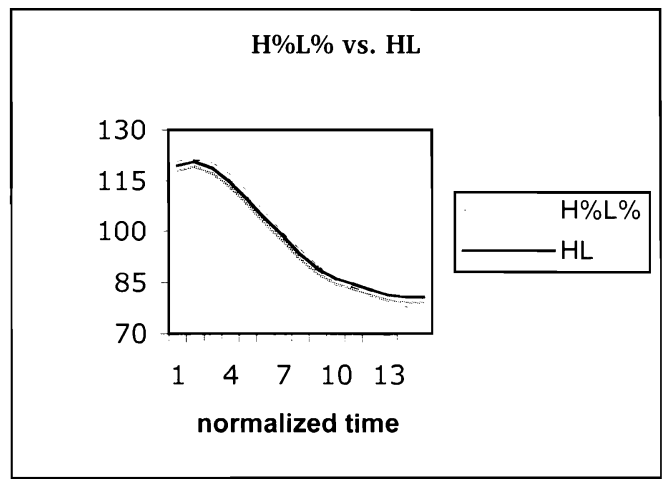

As a purely notational convenience, we follow Mutaka (1994) in transcribing the $\mathrm{H} \%$ with the umlaut sign (thus, e-ki-ryätu 'shoe' vs. e-ki-hánde 'cloth'). As seen in (2), there is no phonetic difference between these two structurally different tones. 
Simplex (nonderived) nominals come in two basic varieties in Kinande: monosyllabic and disyllabic. As in most other Bantu languages, the latter class outnumbers the former by a considerable degree and indicates that CVCV is the canonical stem shape for nominals. In our hand count of the reconstructed nominal stems in Guthrie (1971), we find c. 998 disyllables vs. c. 111 monosyllables. As far as the disyllabic tonal classes of Proto-Bantu are concerned, they occur in the order $/ \mathrm{HL} />/ \mathrm{LL} />/ \mathrm{LH} />/ \mathrm{HH} /$ with the frequencies shown in the table below in (3a). In monosyllables, $\mathrm{H}$ outnumbers L. For purposes of comparison we show the Proto-Bantu reflexes that have survived into Kinande in (3b). The relative proportions are comparable to those in $(3 \mathrm{a})$ and provide some confidence that the inherited vocabulary more or less faithfully reflects their Proto-Bantu source with no obvious skewing.

a. Proto-Bantu tonal classes (Guthrie 1967)

$\begin{array}{cccccccl}\text { HL } & \text { LL } & \text { LH } & \text { HH } & \text { Total } & \text { H } & \text { L } & \text { Total } \\ 344 & 315 & 192 & 147 & 998 & 77 & 34 & 111 \\ .34 & .31 & .19 & .15 & & .69 & .31 & \end{array}$

b. Proto-Bantu reflexes in Kinande

$\begin{array}{llllllll}\text { HL } & \text { LL } & \text { LH } & \text { HH } & \text { Total } & \text { H } & \text { L } & \text { Total } \\ 78 & 52 & 28 & 24 & 182 & 14 & 10 & 24 \\ .42 & .29 & .15 & .13 & & .58 & .42 & \end{array}$

\section{PB Reflexes in Kinande and Lacustrine Bantu.}

We now turn to the reflexes of the PB tonal classes in our c. 200 word Kinande corpus, starting with the disyllabic stems.

3.1 HL. The corpus contains c. 80 PB HL stems from Guthrie (1967-1971) that have reflexes in Kinande. Over three-quarters are matched by cognates in Runyankore, Jita, or Haya. The regular Kinande correspondence is with a $\mathrm{H}$ on the syllable preceding the stem: 69/80. A few examples are shown below in (4). The first group comprises $/ \mathrm{H} 0$ / stems that host the Kinande $\mathrm{H} \%$ boundary tone and the second /HL/ stems which repel it. As we see, both classes regularly correspond to $\mathrm{H} 0$ stems in Runyankore, Haya, and Jita and to HL in the Guthrie reconstruction, posing an intriguing problem as to the origin of this apparent tonal split. We return to this puzzle in section 3.4. (Aside from the umlaut sign, our transcriptions are faithful to the source.) 
(4) Reflexes of PB HL stems

\begin{tabular}{|c|c|c|c|c|c|}
\hline$P B$ & gloss & Kinande & Runyankore & Haya & Jita \\
\hline gứtà & oil & amágüta & amajúta & amajûta & lifú:ta \\
\hline cúkà & hoe & eyịsüka & efúka & enfûka & i:nsúka \\
\hline pínì & hoe handle & omúhïni & omuhíni & omuîni & \\
\hline dími & tongue & olúlïmi & orurimi & olulîmi & olulimi \\
\hline kátà & headpad & éngäta & engáta & engâta & i:ngáta \\
\hline yúmà & iron & ékyüma & ekyô:ma & ekyô:ma & \\
\hline yánà & child & ómwäna & & & omwá:na \\
\hline ádà & charcoal & eríkäla & i:kára & eikâra & likára \\
\hline ídà & tail & omukíra & omukíra & omukîra & omukíra \\
\hline <úbà & chest & ekị́küba & ekifúba & ekifûba & ecifúBa \\
\hline ámà & cheek & erítëma & i:táma & eitâma & litáma \\
\hline óbà & animal skin & ekíkoba & ekikóba & ekikôba & \\
\hline pémbè & horn & erínembe & i:hê:mbe & eiyêmbe & liyé:mbe \\
\hline kókò & chicken & éngoko & enkóko & enkôko & i:nkóko \\
\hline súngù & eagle & ekíhungu & empû:ngu & ekiûngu & \\
\hline tándà & bed (for wood) & ekítanda & ekitâ:nda & ekitânda & ecitá:nda \\
\hline ádà & granary & ekítara & ekitára & & ecitára \\
\hline búmbà & clay & eríbumba & i:bû:mba & eibûmba & liBú:mba \\
\hline kúmù & medicine man & omúkựmus & omufúmu & omufûmu & \\
\hline & pus & eríshira & & & $\mathrm{am}$ \\
\hline & trap & ekítego & & & omutégo \\
\hline
\end{tabular}

Thus, Kinande has retracted the $\mathrm{H}$ one syllable to the left on to the noun class prefix. If the latter lacks a vowel or has had its vowel devocalized before a vowelinitial stem then the $\mathrm{H}$ appears on the pre-prefix, as in é-n-gäta 'headpad' and $o$ $m w$-äna 'child'. While one might wish to interpret the retraction as a response to crowding by the boundary $\mathrm{H} \%$, the fact that it regularly occurs in $/ \mathrm{HL} / \mathrm{stems}$ that block the attachment of $\mathrm{H} \%$ indicates that there is no direct connection between these two hallmarks-retraction to the prefix and $\mathrm{H}-\mathrm{L} \%-$ of the Kinande language.

We now turn to the exceptions to the regular correspondence. First, a handful of PB HL items appear with the toneless /00/ reflex in Kinande. 
/00/ reflexes of PB HL stems

\begin{tabular}{|c|c|c|c|c|c|}
\hline$P B$ & gloss & Kinande & Runyankore & Haya & \\
\hline un & ten & erikümi & i:kúmi & eikûmi & \\
\hline tétè & reed & ekitetë & omutê:te & & \\
\hline
\end{tabular}

Seven items appear in the e-ki-hánde class (6). The first five are plausibly loans from penultimate-stress Swahili. ${ }^{2}$ (The bh of omubhángä is a digraph indicating that the consonant is a stop; single $b$ denotes a fricative intervocalically.)

\begin{tabular}{|c|c|c|c|c|c|}
\hline$P B$ & gloss & Kinande & Runyankore & Haya & Swahili \\
\hline címbà & lion & eșímbä & & & simba \\
\hline kóópì & slap & erikófị & & & kofi \\
\hline yánị & leaf & olusyáni & & & jani \\
\hline kómbè & cup & ekikómbe & & ekikômbe & kombe \\
\hline pángà & bushknife & omubháng & & & panga \\
\hline yínò & tooth & eríno & erî:no & elîno & jino \\
\hline úbà & sun & eryúba & i:zô:ba & eizô:ba & jua \\
\hline
\end{tabular}

Finally, three PB HL stems gímà 'monkey', tádè 'iron ore', and pácà 'axe' have Kinande reflexes with a double $\mathrm{H}$ : éngíma, erítále, émbása. Most lack cognates in the closely related Runyankore, Haya, and Jita.

3.2 LL. The corpus contains 49 Kinande stems that reconstruct as PB LL. Fortyone have the expected development as the $/ 00 /$ e-ki-ryätu category $(\mathrm{N}=37)$ or the /0L/ e-ki-tsungu $(\mathrm{N}=4)$. A few examples are cited below in (7), with cognates

${ }^{2}$ It is interesting that as far as the Kinande citation form is concerned, the penultimate stress of Swahili would be compatible with either the phonologically stable high of $e$-ki-hánde or the boundary $\mathrm{H} \%$ of $e-k i-r y a ̈ t u$. Kinande systematically takes the first option. Runyankore makes a similar choice in its adaptation of Swahili (and English) loans. For example, in our hand count of the first fifty loans in Kaji's (2007) Runyankore lexicon, we find only a handful of items in the alternating class (marked with an umlaut). The vast majority are adapted with the stable accent: embarâ:si < Sw farasi 'horse', engamíra < Sw ngamia 'camel', but kä:wa (cf. $k a$ :wá yangye 'my coffee') < Sw kahawa 'coffee'. This adaptation may indicate a dispreference for alternating $\mathrm{H}$ or alternatively that the loan is adapted from a phrase-medial context in Swahili where the penultimate stress = high tone correspondence would require assigning the word to the nonalternating class in Kinande. 
from Runyankore, Haya, and Jita, which also show this regular development. It manifests the frequently made observation that $\mathrm{L}$ tones tend to be inert in Bantu languages.

(7) $/ 00 /$ and $/ 0 \mathrm{~L} /$ reflexes of PB LL stems

\begin{tabular}{|c|c|c|c|c|c|}
\hline$P B$ & gloss & Kinande & Runyankore & Haya & Jita \\
\hline mèdò & gullet & omumëro & omumiro & omumiro & limiro \\
\hline gòmà & drum & engöma & engoma & engoma & i:ngoma \\
\hline gùdù & leg & okugülu & okuguru & okuguru & okuguru \\
\hline làmà & muscle,meat & enyäma & enyama & eñama & i:ñama \\
\hline gànjà & palm of hand & ekigänza & ekigaanja & ekiganja & ecigá:nja \\
\hline idi & body & omubïri & omubiri & omubili & omubiri \\
\hline k & soil & ekitäka & i:taka & eitaka & litaka \\
\hline dò & fire & omuliro & omuriro & omulilo & omuliro \\
\hline & locust & engike & enzigye & enzigye & i:njige \\
\hline & & ekirago & & & echirago \\
\hline
\end{tabular}

The items in (8) have been reclassified into the $e$-ki-hánde class, suggesting that they have been reanalyzed on the basis of the ambiguous citation form. The first five are shared with the Kavutirwaki (1978) dictionary. The last two are the tone patterns assigned by our consultant; the dictionary retains the etymologically expected enyöndo and enzögu.

(8) stable /HL/ reflexes of PB LL stems

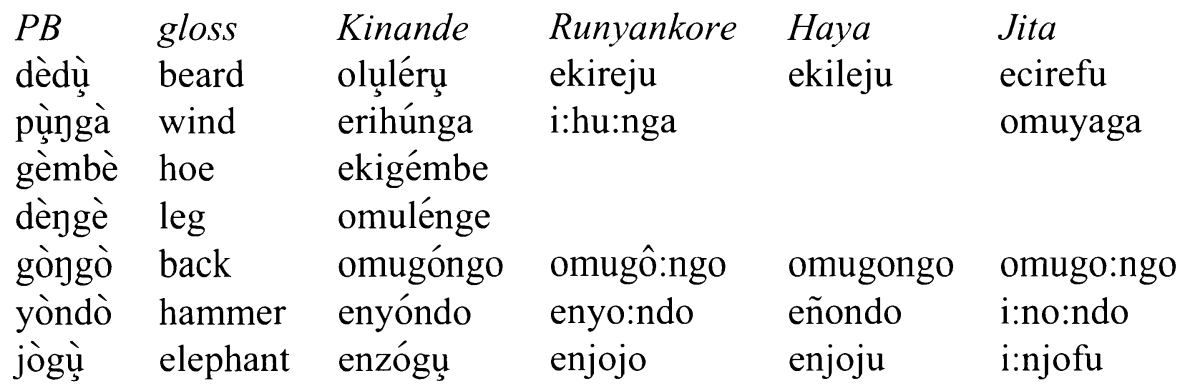

In this lexical restructuring we see that the stems have been reclassified on the basis of the ambiguous isolation form with a penultimate high tone. Thus, the smaller $e$-ki-hánde class attracts items from the larger $e$-ki-ryätu class in addition 
to being the repository of Swahili loans. The reason presumably is that this tonal class is phonologically stable (no alternation). ${ }^{3}$

3.3 LH. Our corpus contains 24 reflexes of the PB LH class. It has a more varied outcome compared to PB HL and LL. Twelve items are reflected as the fixed penultimate $\mathrm{H}$ of $e$-ki-hánde, with a retraction of the final $\mathrm{H}$. Several are matched by a Runyankore or Haya cognate whose final accent in phrase-medial position directly mirrors the PB source. Ukerewe Jita is most faithful to PB since it lacks the retraction of the $\mathrm{H}$ that is found in the phrase-final forms of Runyankore and Haya.

(9) stable /HL/ reflexes of PB LH stems

\begin{tabular}{|c|c|c|c|c|c|}
\hline & $\begin{array}{l}\text { gloss } \\
\text { pot } \\
\text { bodyhair } \\
\text { cloth } \\
\text { hole } \\
\text { brain } \\
\text { long rain } \\
\text { partridge } \\
\text { house } \\
\text { mud }\end{array}$ & $\begin{array}{l}\text { Kinande } \\
\text { enyúngu } \\
\text { olwéya } \\
\text { ekihánde } \\
\text { ekyúna } \\
\text { obóngo } \\
\text { omụlúmbís } \\
\text { engwáli } \\
\text { enyúmbä } \\
\text { obudóngo }\end{array}$ & $\begin{array}{l}\text { Runyankore } \\
\text { enyu:ngu } \\
\text { orwo:ya }\end{array}$ & $\begin{array}{l}\text { Haya } \\
\text { eñúngu } \\
\text { omwó:ya } \\
\text { olupánde } \\
\text { eḱ1:na } \\
\text { obwôngo }\end{array}$ & $\begin{array}{l}\text { i:nkwa:rê } \\
\text { i:ñú:mba }\end{array}$ \\
\hline
\end{tabular}

Six Kinande items in the class of PB LH reflexes display the double-H of $e$-kisáka 'branch' (10). Several of the Runyankore or Haya cognates belong to the phrasally alternating class (see (20) below) that reflects their LH provenance. They are marked here with an umlaut.

${ }^{3}$ A similar phenomenon appears in Russian where loans systematically join the fixed accent class. The alternating (mobile) class is much smaller (c. $2 \%$ of the native Russian lexicon) and so the preference for the fixed class is ambiguous between frequency and stability. The Kinande data suggest that a stable phonological form can be decisive. 
(10) double-H reflexes of PB LH

$\begin{array}{llllll}P B & \text { gloss } & \text { Kinande } & \text { Runyankore } & \text { Haya } & \text { Jita } \\ \text { càká } & \text { bush } & \text { ekísáka } & \text { ekishaka } & \text { ekisháka } & \text { lisakâ } \\ \text { cịcá } & \text { vein } & \text { omúsísa } & \text { omüsi } & \text { omüsi } & \\ \text { pàpá } & \text { wing } & \text { ekị́súpa } & \text { i:papa } & \text { eipäpa } & \text { liBaBâ } \\ \text { pùká } & \text { insect } & \text { ekíhúka } & \text { ekihúka } & \text { ekiüka } & \\ \text { tịḱ́ } & \text { stump } & \text { ekísíki } & \text { ekisï:ku } & & \text { ecisikî } \\ \text { yàtí } & \text { grass } & \text { obúnyátsi } & \text { orunyâ:nsi } & \text { akañâ:si } & \text { liñási }\end{array}$

The Kinande stems in this tone-doubling class all have a voiceless medial consonant-a property that distinguishes them from the e-ki-hánde set in (9). Another one, pointed out by both SAL reviewers, is that the initial syllable of the stem in the items of (9) either begins with a glide or is followed by an NC cluster-both common (compensatory) lengthening sites in Bantu, as evidenced by the forms in Runyankore and Jita.

Two possible reconstructions of the single vs. double-high retraction seen in (9) vs. (10) present themselves. If voicing is the critical factor, we may posit a sound change spreading the word-final $\mathrm{H}$ to the preceding syllable that is blocked by an intervening voiced consonant. This is followed by the general $\mathrm{H}$ retraction that affected HL stems as well. The steps in (11) show this scenario.
(11)
$\begin{array}{ll}\text { /ki-búga/ } & \begin{array}{r}\text { ki-saká/ } \\ \text { ki-sáká }\end{array} \\ \overline{\text { kí-buga }} & \begin{array}{l}\text { ki-sáka }\end{array}\end{array}$
/ki-pandé/
$\overline{\text { ki-pánde }}$
Final H Spreading
General H Retraction

Under the alternative interpretation shown in (12), the second mora of the lengthened vowel is the target of Final H Spreading. Then the more general retraction shifts Hs one mora to the left. Finally, long vowels are merged with short ones.
(12) /ki-búga/ /ki-saká/ /ki-pandé/
ki-paandé

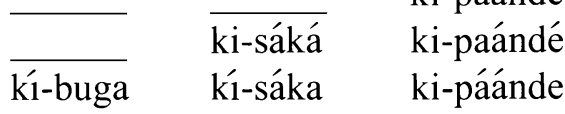
ki-pánde
Vowel Lengthening
Final H Spreading
General H Retraction
Vowel Shortening 
Both alternatives seem plausible on general grounds. ${ }^{4}$ They predict different outcomes for stems whose medial consonant is a plain voiced one with no glide onset. Under the first we expect a single $\mathrm{H}$ tone analogous to ekihánde, while the second predicts doubling in the manner of ekisáka. Our corpus contains three possible stems of this shape, which are listed below in (13).

\begin{tabular}{|c|c|c|}
\hline 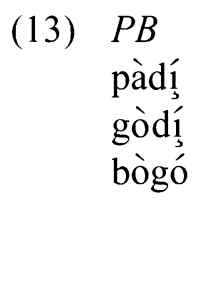 & $\begin{array}{l}\text { Kinande } \\
\text { embäli } \\
\text { omúgóle } \\
\text { embögo } \\
\text { émbógo } \\
\text { embógo }\end{array}$ & $\begin{array}{l}\text { gloss } \\
\text { ant } \\
\text { bride } \\
\text { buffalo }\end{array}$ \\
\hline
\end{tabular}

The Kinande reflexes are unfortunately varied and hence inconclusive. For 'buffalo' embögo is the tonal assignment offered by our consultant. The Mutaka and Kavutirwaki dictionary lists embógo as well as émbógo.

The four PB LH stems in (14) have joined the toneless class in Kinande and for the most part in Runyankore, Haya and Jita as well.

(14) PB LH with Kinande toneless reflexes

$\begin{array}{llllll}P B & \text { gloss } & \text { Kinande } & \text { Runyankore } & \text { Haya } & \text { Jita } \\ \text { nòní } & \text { bird } & \text { enyönyu } & \text { ekinyonyi } & \text { ekiñoñi } & \text { i:ñoñi } \\ \text { bògó } & \text { buffalo } & \text { embögo } & \text { embogo } & \text { embógo } & \text { i:mbogô } \\ \text { pàdí } & \text { ant } & \text { embälị } & \text { empazi } & \text { obwa:zi } & \text { i:mpaji } \\ \text { yèndá } & \text { nine } & \text { omwënda } & \text { omwenda } & \text { omwenda } & \end{array}$

We conclude that for the PB LH class, the $\mathrm{H}$ is retracted from its etymological position as either a single (9) or double (10) peak. The split is based on either the voicing category of the medial consonant or alternatively on the length of the preceding vowel. Another important reflex of this class is that it resists the attachment of the $\mathrm{H} \%$ to the final syllable. As we shall see, this behavior is distinct from the monosyllabic $\mathrm{H}$. That is, while PB dó gives e-kí-rö 'night', enyúngu 'pot' < nùygú and o-mú-sísa 'vein' < cìcá block the H\% attachment.

${ }^{4}$ The majority of the Runyankore forms in (9) have a long vowel and also have no high tone. This might reflect a dispreference for rising tones *enyŭ:ngu and final peaks *enyu:ngú at the cost of deletion of the $\mathrm{H}$. 
3.4. PB HL vs. HH and the Kinande /HO/ vs. /HL/ Contrast. In a paper important to our topic, Meeussen (1976) called attention to certain inaccuracies in Guthrie's PB tonal reconstructions, especially with regard to the lexical items belonging to the PB HL and HH classes. Based on material in Greenberg (1948) and his own research, Meeussen proposed for example that Guthrie's HL reconstructions for kadi 'woman' and kingo 'neck' be replaced with HH while Guthrie's HH for kige 'eyebrow' be replaced by HL. More significantly for our purposes, in the course of his discussion Meeussen states that PB HH is reflected as Kinande H-LL while PB HL is reflected as Kinande H-HL. In other words, the apparent puzzling split of Guthrie's HL class into Kinande stems such as $o$-múlüme 'man' with a final $/ 0$ / that accepts the boundary tone vs. stems such as $o$-múkali 'woman' with a final /L/ that repels it can actually be traced back to the /HL/ vs. $/ \mathrm{HH} /$ distinction in Proto-Bantu.

In an effort to determine the viability of Meeussen's reconstructions as the basis for the Kinande $o$-mú-lüme vs. o-mú-kali contrast, we constructed a corpus of c. 100 Kinande cognates drawn from lexicons of the reversing languages ChiLuba (Yukawa 1992) and Tembo (Kaji 1986) as well as Lingala (Kaji 1992). These are so-called "clear" languages in which the PB four-way tonal distinction is preserved and differ from Lacustrine languages such as Runyankore, Haya, and Jita which have merged HH and HL (Philippson 1998). In the reversing languages, $\mathrm{PB} \mathrm{H}$ and $\mathrm{L}$ appear to have interchanged so that $\mathrm{PB} \mathrm{HH}$ is reflected as $\mathrm{LL}$ and PB HL is reflected as LH. See Appendix B for the corpus.

Here are the results. We find a fairly regular correspondence (29/39) between Kinande $/ \mathrm{H} 0 /=\mathrm{H}-\mathrm{HL} \%$ and $\mathrm{PB} \mathrm{HL}$ (reflected as $\mathrm{LH}$ in the reversing languages). Some examples appear below, showing the Guthrie reconstruction. These correspondences suggest that PB yádá 'fingernail' and dámú 'sister-inlaw' should be reassigned to the HL class.

(15) PB HL reflexes

$\begin{array}{llllll}P B & \text { gloss } & \text { Kinande } & \text { Tembo } & \text { Luba } & \text { Lingala } \\ \text { dúmè } & \text { man } & \text { omúlüme } & \begin{array}{l}\text { múlumé } \\ \text { múlumé }\end{array} & \\ \text { dími } & \text { tongue } & \text { olúlimi } & \text { lúlimí } & \text { lúdimí } & \text { lolémo } \\ \text { támà } & \text { cheek } & \text { erítëma } & \text { étamá } & \text { dítamá } & \text { litáma } \\ \text { béédè } & \text { breast } & \text { eríbëre } & \text { éberé } & \text { díbeelé } & \text { libéle } \\ \text { yádá } & \text { fingernail } & \text { ékyäla } & & \text { lwáalá } & \\ \text { kúpà } & \text { bone } & \text { eríküha } & & \text { máfufwá } & \text { mokúwa } \\ \text { kídà } & \text { tail } & \text { omúkïa } & \text { múkirá } & \text { múkilá } & \text { mokíla } \\ \text { cúkà } & \text { hoe } & \text { eý́süka } & & \text { nkasú } & \end{array}$




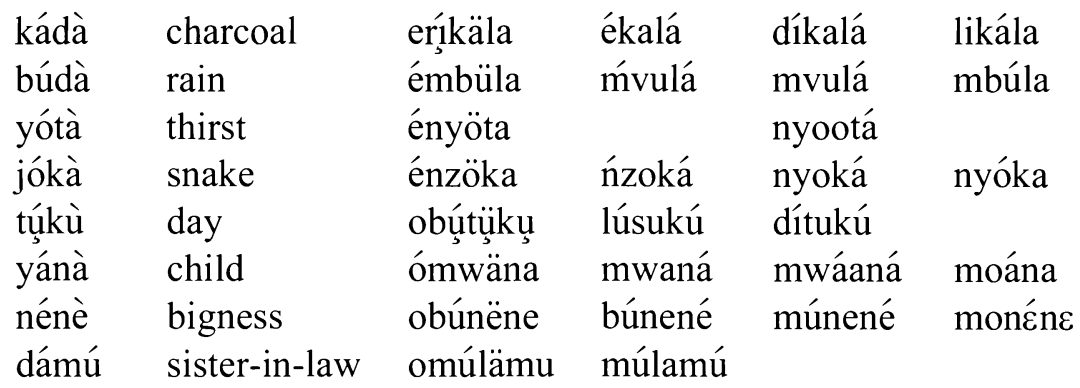

For the smaller PB HH class, we have 19/21 correspondences between Kinande $/ \mathrm{HL} /=\mathrm{H}-\mathrm{OL}$ and $\mathrm{PB} \mathrm{HH}$ (reflected as LL in Luba and Tembo). The forms marked $\mathrm{M}$ in the table below are Meeussen's (1976) alternative reconstructions to Guthrie's HL. The correspondences suggest that bumba 'clay' should be reconstructed as $\mathrm{HH}$. The last two items are anomalous. Kinande olúhala is consistent with PB HH while the Tembo and Luba reflexes suggest PB HL, which should yield olúhäla in Kinande. Luba dipasá is consistent with Guthrie's HL reconstruction but should give omúhäsa in Kinande. The words in the final column are from Lingala (L), Lomongo (M) or Bemba (B).

(16) PB HH reflexes

\begin{tabular}{|c|c|c|c|c|c|}
\hline $\begin{array}{l}P B \\
\operatorname{kád}^{\prime}(\mathrm{M})\end{array}$ & $\begin{array}{l}\text { gloss } \\
\text { woman }\end{array}$ & $\begin{array}{l}\text { Kinande } \\
\text { omúkali }\end{array}$ & $\begin{array}{l}\text { Tembo } \\
\text { múkasi }\end{array}$ & $\begin{array}{l}\text { Luba } \\
\text { múkaji }\end{array}$ & $\begin{array}{l}\text { Lingala } \\
\text { moásí (L) }\end{array}$ \\
\hline $\begin{array}{l}\text { búmbà } \\
\text { kókó(M) }\end{array}$ & clay & eríbumba & ńgok & lúpeemba & \\
\hline $\begin{array}{l}\text { KOKO(IVI) } \\
\text { túmbími }\end{array}$ & chair,stool & ekítumbi & cífumbi & & КОКО (IVI) \\
\hline yáyú(M) & yawn & émyaya & & mwáau & \\
\hline cíndí & squirrel & ekísindi & & nshiindi & \\
\hline kứṕ1 & shortness & ekíkushị & & bwíipi & \\
\hline pídá(M) & pus & eríhinira & másira & túfina & mayíná (L) \\
\hline kúdú(M) & oldness & obúkulu & múkulu & búkulúumpé & kúlú (M) \\
\hline bánjá(M) & courtyard & ekíbanza & ć́banja & banza(M) & \\
\hline kóbá(M) & skin & éngoba & ć́koba & díkoba & \\
\hline púngú(M) & eagle & ekíhungu & & & púngú $(\mathrm{M})$ \\
\hline kứmú́ & witchdoctor & omứkựụ & & fumu(M) & \\
\hline kédé(M) & frog & ekíkere & cíkere & & \\
\hline jábú & beer & óbwabus & mafu & & \\
\hline júká & breath & ómuka & muka & & \\
\hline jámí (M) & chief & ómwami & & & ámí (B) \\
\hline
\end{tabular}




\begin{tabular}{llllll} 
ḉmbá(M) lion,wildcat & eýsisimba & & \multicolumn{2}{c}{ Jimba(M) } \\
pádá & baldness & olúhala & lúala & díbalá & \\
pácà & twin & omúhasa & & dípasá & lipása (L)
\end{tabular}

We conclude that Meeussen's reconstructions are correct and that the source of the Kinande / $\mathrm{H} 0 /$ vs. / $\mathrm{HL} /$ contrast is $\mathrm{PB} \mathrm{HL}$ vs. $\mathrm{HH}$.

3.5. Monosyllables. Our corpus contains 24 stems that can be traced back to monosyllables in the Guthrie $\mathrm{PB}$ reconstruction: 17 reconstruct as $\mathrm{H}$ and 9 as $\mathrm{L}$. The PB H stems appear in Kinande with the $\mathrm{H}$ on the preceding prefix, reflecting the retraction also seen in the disyllabic /LH/ stems. Most also allow the attachment of the $\mathrm{H} \%$ boundary tone. Nine stems can be traced back to PB L. All except $d i$ 'long, tall' have /0/ reflexes in Kinande that allow attachment of the $\mathrm{H} \%$ boundary tone. ${ }^{5} \mathrm{We}$ include $\mathrm{CVV}$ stems where the first vocoid is realized as a glide and the resultant CGV syllable counts as a single tone-bearing unit. The umlaut indicates Runynakore and Haya stems whose $\mathrm{H}$ alternates with phrasemedial forms where it appears on the stem in its etymological position.

(17) PB monosyllable reflexes

\begin{tabular}{|c|c|c|c|c|c|}
\hline $\begin{array}{l}\text { gloss } \\
\text { face }\end{array}$ & $\begin{array}{l}\text { Kinande } \\
\text { obúsö }\end{array}$ & Luba & $\begin{array}{l}\text { Runyakore } \\
\text { obüso }\end{array}$ & $\begin{array}{l}\text { Haya } \\
\text { obüso }\end{array}$ & $\begin{array}{l}\text { Jita } \\
\text { oBusû }\end{array}$ \\
\hline ear & okútü & dícu & okütu & okütwi & okutwî \\
\hline night & ekírö & dílolo & ekïro & ekíro & \\
\hline bow & obútä & & obuta & akäta & \\
\hline excrement & amábị & túuf́ & amäzi & amäzi & \\
\hline corpse & omụkụ̈ & & omüfu & omüfu & omufû \\
\hline smallness & obúkë & búkése & & & \\
\hline outside & eyị́hyä & & & & a:njâa \\
\hline knee & erírwï & & oküju & oküjwi & \\
\hline food & akályö & & ekyókürya & ekya:külya & eBilyô \\
\hline fish & ekítswë & & & & i:nswî \\
\hline
\end{tabular}

\footnotetext{
${ }^{5}$ Aside from ekïndu 'thing' monosyllabic stems do not permit the $\mathrm{H} \%$ boundary tone to associate to the prefix. Working within the framework of Lexical Phonology where word-level phonology precedes phrase-level phonology, Mutaka (1994) postulates an underlying long vowel for the root so that the $\mathrm{H} \%$ associates to the phonological penult. The more plausible alternative is to allow the phrase-level phonology access to the word-internal structure. See Odden (1996) for other examples in which phrasal phonological processes such as the shortening of a pre-complement long vowel in Kimatuumbi is sensitive to the prefix-stem parse.
} 


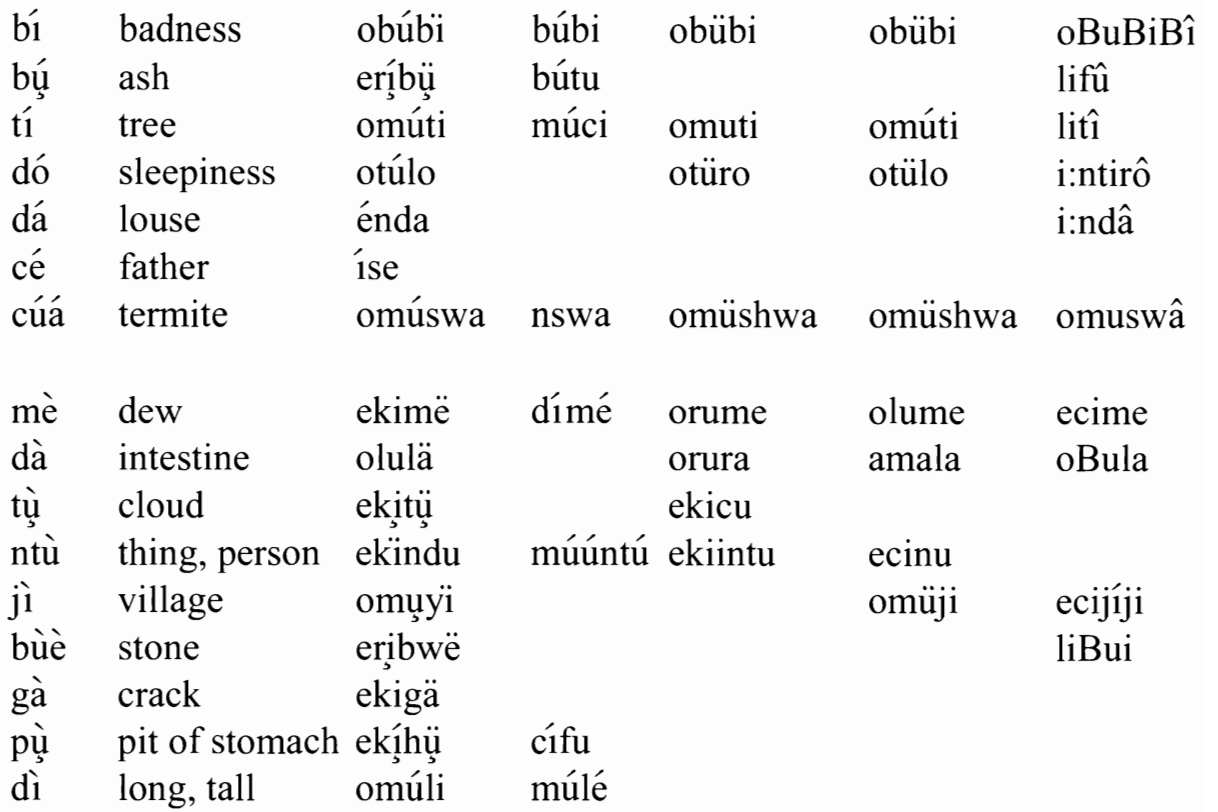

The following table summarizes the regular developments of the PB tonal classes in Kinande. Five of the six subtypes for disyllabic stems in the Hyman typology of (1) have been traced. The /0L/ class represented by e-ki-tsungu 'potato' remains to be accounted for. See section 5 .

(18) PB canonical reflexes

$\begin{array}{llll}\text { PB } & \text { example } & \text { Kinande } & \text { gloss } \\ \text { HL } & \text { dúmè } & \text { o-mú-lüme } & \text { man } \\ \text { HH } & \text { kádì } & \text { o-mú-kali } & \text { woman } \\ \text { LL } & \text { mèdò } & \text { o-mu-mëro } & \text { gullet } \\ \text { LH } & \text { dùmbé } & \text { o-mư-lúmbị } & \text { long rain } \\ \text { LH } & \text { pùká } & \text { e-kí-húka } & \text { insect } \\ \text { H } & \text { tú } & \text { o-kú-tö } & \text { ear } \\ \text { L } & \text { mè } & \text { e-ki-më } & \text { dew }\end{array}$

\section{Chronology}

In many Eastern Bantu languages the PB H vs. L contrast was reinterpreted as $\mathrm{H}$ vs. 0 (Clements \& Goldsmith 1984). This restructuring helps to explain the long distance displacement of $\mathrm{H}$ tones found in such languages as Digo (Kisseberth 
1984) and Chizigula (Kenstowicz \& Kisseberth 1990) as well as rhythmic alternations of $\mathrm{H}$ such as those found in Kirundi (Goldsmith \& Sabimana 1985). With a syllable's L reanalyzed as 0 , it no longer blocks the drift of $\mathrm{H}$ nor buffers adjacent Hs, which tend to keep a respectable distance from one another. A major motivation for the reanalysis and switch to an accentual system was the merger of the HH class with HL, which Clements \& Goldsmith (1984:7) dub "Meeussen's Rule"; cf. Philippson (1998). The result was an inventory of tonal contours with just one $\mathrm{H}$ peak, which could be reanalyzed as a "head" governing a domain of toneless syllables. The verb had the potential for an accentual interpretation already in $\mathrm{PB}$ since the $\mathrm{H}$ vs. $\mathrm{L}$ lexical contrast was restricted to the initial syllable.

We may account for the difference between Kinande vs. the Lacustrine languages Runyankore, Haya, and Jita by assuming different chronologies in the $\mathrm{HH}>\mathrm{HL}$ and $\mathrm{L}>0$ changes, as shown in (19). In the Lacustrine languages $\mathrm{HH}>\mathrm{HL}$ occurred before the reanalysis of $\mathrm{L}$ as 0 so that any trace of a distinction between the PB HH vs. HL stem classes was eliminated. In Kinande, on the other hand, $\mathrm{L}>0$ occurred first with the subsequent $\mathrm{HH}>\mathrm{HL}$ (perhaps via an intermediate downstepped $\mathrm{H}^{\prime} \mathrm{H}$ ) producing the three-way $\mathrm{H}$ vs. L vs. 0 contrast on the final syllable that is the basis of the o-mú-lüme vs. o-mú-kali puzzle we have been trying to explain and that prompted Hyman \& Valinande (1985) to posit a global rule for a comparable contrast in the verbal inflection.

(19) reconstruction of tonal classes

Lacustrine Bantu

$\begin{array}{lllll}\text { PB } & \text { HL } & \text { HH } & \text { LH } & \text { LL } \\ \text { HH }>\text { HL } & \overline{H L} & & \\ \text { L }>0 & \text { H0 } & \text { H0 } & \overline{0 H} & \overline{00} \\ \text { surface } & \text { H0 } & \text { H0 } & 0 \mathrm{H} & 00\end{array}$

$\begin{array}{lllll}\begin{array}{l}\text { Kinande } \\ \mathrm{PB}\end{array} & \mathrm{HL} & \mathrm{HH} & \mathrm{LH} & \mathrm{LL} \\ \mathrm{L}>0 & \mathrm{H} 0 & \overline{\mathrm{HL}} & \overline{\mathrm{H}} & 00 \\ \begin{array}{l}\mathrm{HH}>\mathrm{HL} \\ \text { surface }\end{array} & \overline{\mathrm{H} 0} & \mathrm{HL} & \overline{\mathrm{OH}} & \overline{00}\end{array}$

The Kinande split of the PB LH class into LH vs. HH on the basis of either the voicing of the medial consonant or the postulated vowel length (recall (9) vs. (10)) allows us to pinpoint the $\mathrm{H}$ retraction of PB LH as later in the chronology. The development of the double $\mathrm{H}$ must have occurred after $\mathrm{HH}>\mathrm{HL}$. Otherwise 
PB pùká 'insect' would have joined HH kádì and should appear as Kinande e-kí$h u k a$ instead of the attested $e-k i$-húka. On the other hand, it must have preceded H-retraction to account for the fact that both H's are shifted one syllable/mora leftward in e-ki-húka as well as to ensure that the medial consonant that conditions the split still separates the two stem syllables. As a result of the split of the PB LH class, Kinande had five tonal categories for disyllabic stems (H0, HL, OH, $\mathrm{HH}, 00)$ in contrast to just three for Lacustrine Bantu $(\mathrm{H0}, 0 \mathrm{H}, 00)$.

Subsequently, Kinande as well as Runyankore and Haya (but not Jita) retract $\mathrm{H}$ from the final syllable. Poletto (1998) treats the phenomenon in Runyankore as crowding by a L boundary tone. For Haya Hyman \& Byarushengo (1984) derive the retracted prepausal form obugólo 'snuff' (cf. obugoló bwange 'my snuff') via an intermediate form obugóló in which the final $\mathrm{H}$ has spread to the preceding syllable. This spread $\mathrm{H}$ tone appears in certain phrasal contexts such as before a vocative noun: obugóló káto '(the) snuff, Kato'. In Runyankore and Haya the retraction occurs at the end of a phrase and leads to regular alternation between a phrase-final retracted form and a phrase-medial form with accent on the final syllable (20). In Runyankore retraction produces surface merger with the original $\mathrm{H} 0(<\mathrm{HL})$ class if the penult is short. If the penult is long the contrast is realized as Fall vs. H. Haya maintains the contrast as Fall vs. H for both long and short syllables.

(20)

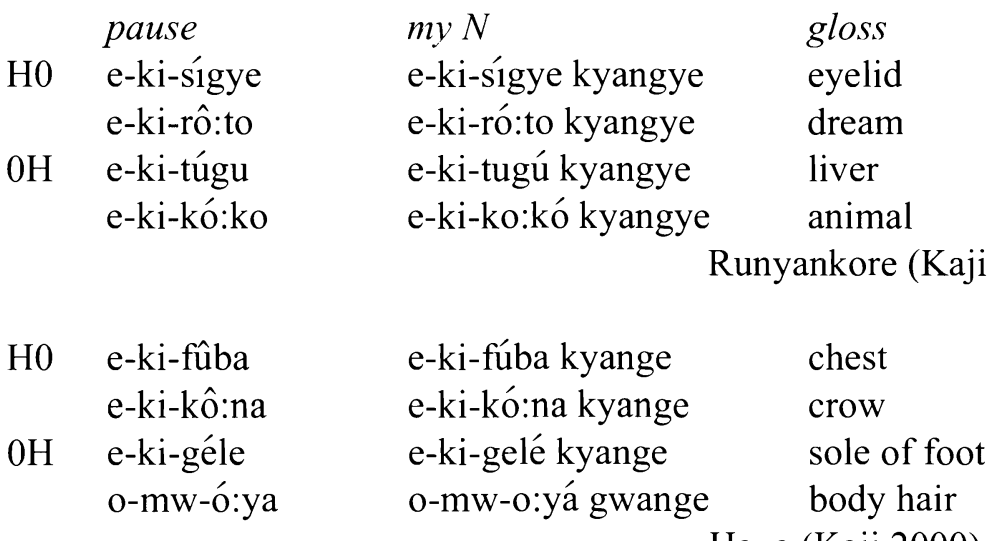

Haya (Kaji 2000)

In Kinande the retraction of the $\mathrm{PB}$ word-final $\mathrm{H}$ differs from Lacustrine Bantu in a number of respects, suggesting that it was probably a separate development. First, the language eliminated the PB vowel length contrast (while retaining the [ATR] contrast for high vowels). Thus, a surface contrast in short vs. 
long syllables was not available to express the distinction between original and retracted H's. There are other differences as well. First, retraction in Kinande does not result in phrasal alternations: a PB LH stem like pàndé 'piece of cloth' from (9) appears as e-ki-hánde with a stable H. In contrast PB pùká 'insect' alternates in Runyankore (ekihúka, ekihuká kyange 'my insect') and Haya (ekiúka, ekiuká kyange). Second, in Kinande all stem $\mathrm{H}$ tones retracted-not just those on the final syllable-presumably to allow more comfortable phonetic expression of the larger range of tonal classes. The noun class prefixes were all toneless in PB and offered a tempting Lebensraum for the more crowded stem inventory. As shown below, the $\mathrm{H}$ retraction allowed a system of surface tonal contrasts to emerge in which there is just a binary opposition for any of the three positions (final, penult, antepenult) in exchange for the earlier (underlying) three-way contrast on final syllables.
(21) early
$0-\mathrm{HL}$
$0-\mathrm{H} 0$
$0-0 \mathrm{H}$
0 - $\mathrm{HH}$
$0-00$
H-retraction $\quad \mathrm{H}-\mathrm{OL}$
$\mathrm{H}-\mathrm{00}$
0 -HL
$\mathrm{H}-\mathrm{HL}$

surface tonal oppositions

$\begin{array}{ll}\text { antepenult: } & \text { H vs. } 0 \\ \text { penult: } & \text { H vs. } 0 \\ \text { final: } & \text { L vs. } 0\end{array}$

Another point worth making concerns the limited distribution of the $\mathrm{L}$ in the reconstruction of (21). It is restricted to occur in the context $\mathrm{H}_{\text {_ \#. This }}$ phonotactic restriction helps to explain another puzzling asymmetry in Kinande tonal development. In the wake of retraction of the final $\mathrm{H}$, the Kinande system of contrasts allowed two alternative interpretations of the final syllable's nonhigh pitch: /L/ or $/ 0 /$. There is an interesting difference between the monosyllables and disyllables here. For the LH disyllables with PB cognates, 14/15 chose $/ \mathrm{HL} /$, which blocks the $\mathrm{H} \%$, as in e-ki-hánde. But monosyllables such as $o-k u$-tü $<\mathrm{PB}$ tú 'ear' chose /H0/ at a 13/17 rate. This difference between the monosyllables and disyllables presumably reflects the fact that $/ \mathrm{HL} /$ originated from $\mathrm{PB} \mathrm{HH}$ structures in the disyllabic stems. Under a minimal generalization learner (Albright \& Hayes 2002) such factors as the location of the morpheme junctures could be taken into account in the transmission and reconstruction of the grammar from one generation to the next so that the phonotactic constraint that restricts $\mathrm{L}$ to the $\mathrm{H}$ _ \# context could include the tautomorphemic factor as well. If this tautomorphemic property is factored into the phonotactic restriction then a $/ \mathrm{L} /$ analysis for the retraction site in monosyllables such as $o-k \dot{u}$-tü would be precluded since the 
$\mathrm{H}$ shifted to the prefix and is hence no longer in the stem. However, it should be noted that we still lack an explanation for the uniform $/ \mathrm{L} /$ choice for the disyllables since in principle both $/ \mathrm{HL} /<\mathrm{HH}$ and $/ \mathrm{HO} /<\mathrm{HL}$ analyses were available. The former preserves an association line, albeit one that is linked to a different tone. If faithfulness to association lines governs input-output relations then this might be a reason to prefer / HL/ over / H0/. The Optimal Domains Model of autosegmental phonology (Cassimjee \& Kisseberth 1998) in which a feature specification is accompanied by a domain or span indicating its scope offers another possible interpretation in which two domains are combined into a single one so that $(\mathrm{H})(\mathrm{H})>(\mathrm{H} 0)$ is distinct from $(\mathrm{H}) 0$.

Upon the completion of $\mathrm{H}$ retraction and in the absence of any alternations between the penult and final syllable for the e-ki-hánde class, we assume that the inventory of tonal classes was restructured, as indicated in (22). The Kinande disyllabic tonal classes deployed a surface L vs. 0 contrast in final position and a ternary $\mathrm{H}$ vs. floating $\mathrm{H}$ vs. 0 contrast initially.

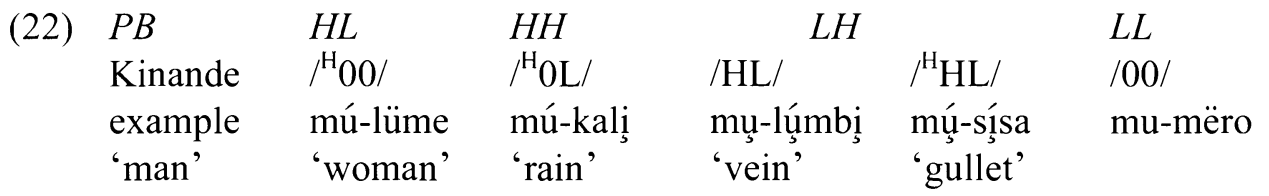

The phonotactic constraint restricting $\mathrm{L}$ to the $\mathrm{H}$ \# context is a relatively complex one since it is composed of three terms and crucially refers to both a lefthand and right-hand context (cf. the model of constraint induction in Hayes \& Wilson (2008) where constraints are preferentially restricted to two terms). Furthermore, a stem's specification as /L/ or /0/ could not be predicted on the basis of phrase-medial contexts such as preadjectival (recall 1). As we will now see, both of these factors played a role in the evolution of the system to its current state.

\section{Extensions.}

The discussion to this point has been restricted to the portion of the Kinande lexicon for which PB cognates are available. This of course is a small fraction of the current lexicon-one that managed to survive many cycles of transmission from one generation of Kinande speakers to the next. What is the inventory and population of the tonal classes in the current language? Here we are indebted to Jones (2007) who classified the nouns (and verbs) in the Kavutirwaki (1978) lexicon with respect to their tonal patterns. In (23) we have reorganized his tabulation of 
the data according to the PB origin of the tonal classes and our postulated reconstruction. Hyman \& Valinande (1985) find a similar distribution for a sample of c. 225 disyllabic noun stems, indicated in the last column of (23). The second last column indicates the class in the Kavutirwaki (1978) lexicon.

\begin{tabular}{|c|c|c|c|c|c|c|c|}
\hline \multirow[t]{9}{*}{ (23) } & $P B$ & example & gloss & size & rep & class & $H \& V$ \\
\hline & $\mathrm{HL}$ & o-mú-lüme & $\operatorname{man}$ & 184 & $/{ }^{\mathrm{H}} 00 /$ & $\mathrm{B}$ & 52 \\
\hline & $\mathrm{HH}$ & o-mú-kali & wife & 221 & $/{ }^{\mathrm{H}} 0 \mathrm{~L} /$ & $\mathrm{D}$ & 50 \\
\hline & LL & e-m-bëba & rat & 298 & /00/ & $\mathrm{A}$ & 59 \\
\hline & & o-mu-genda & moon & 76 & /0L/ & & 11 \\
\hline & LH & e-ki-hánde & piece & 48 & /HL/ & & 24 \\
\hline & & e-ki-dóngö & wall & 20 & $/ \mathrm{H} 0 /$ & & 9 \\
\hline & & é-m-bása & axe & 64 & $/{ }^{\mathrm{H}} \mathrm{HL} /$ & $\mathrm{C}$ & 21 \\
\hline & & o-mú-kékä & mat & 8 & $/{ }^{\mathrm{H}} \mathrm{HO} /$ & & 1 \\
\hline
\end{tabular}

We make several observations with regard to (23). First, the o-mú-kali class originating from $\mathrm{PB} \mathrm{HH}$ with the final /L/ has increased considerably to even surpass the o-mú-lüme class containing descendants of PB HL. This is a rather dramatic change since according to the count in (3) the $\mathrm{HH}$ class was the smallest in PB. It reflects at least in part the ambiguity of the phrase-medial forms (cf. o-múkali $m u$-rïto vs. o-mú-lume $m u$-rï̧to). If a lexical item is first encountered in this context, the Kinande learner must guess whether or not the stem blocks the $\mathrm{H} \%$ attachment and hence has an underlying final /L/. A more evenly balanced distribution across the two classes would be a natural outcome of this ambiguous state of affairs. Moreover, the extension of the o-mú-kali class has proceeded along phonetically natural lines. It has a larger proportion of stems whose medial consonant is a voiced obstruent D or prenasal ND-segments which are known to depress the tone of a following vowel in Bantu (Downing 2009). The specific distribution is shown in (24).

$$
\begin{array}{llllll} 
& T & R & D & N D & \\
\text { o-mú-lüme } & 48 & 84 & 25 & 27 & \mathrm{~T}=\text { voiceless } \\
\text { o-mú-kali } & 60 & 62 & 36 & 63 & \mathrm{R}=\text { sonorant } \\
& & & & & \mathrm{D}=\text { voiced obstruent } \\
& & & & & \mathrm{ND}=\text { prenasal voiced }
\end{array}
$$


A chi-square $2 \times 2$ contingency table for the voicing factors $T+R$ vs. D+ND over the $o$-mú-lüme vs. $o$-mú-kali classes is statistically significant: chi-sq $=13.6, \mathrm{df}=$ $1, \mathrm{p}=0.000$.

The second observation with respect to (23) is that the /L/ vs. /0/ contrast has spread to each of the other classes so that now every tonal category is crossclassified with respect to the dual phonological interpretation of the final syllable-a type of feature economy (Clements 2003). But in each case, the class that represents the original development in our reconstruction outnumbers the innovating class to which the $0 / \mathrm{L}$ contrast has been extended. As a result, the PB LL $>00$ now has a $/ 0 \mathrm{~L} /$ counterpart-the presumed origin of the e-ki-tsungu class from (1). This development indicates that the postulated phonotactic restricting $\mathrm{L}$ to the $\mathrm{H}$ \# context in the reconstruction of (22) has been simplified by dropping the initial term. Moreover, the PB LH class which originally had almost exclusively the final /L/ that blocks the $\mathrm{H} \%$ boundary tone has now gained /0/ counterparts too. This is true for both the double $\mathrm{H}$ from voiceless medial consonants like $o$-mú-kékä as well as the single $\mathrm{H}$ from voiced medials like e-ki-dóngö.

The third observation is that the voicing category of the medial consonant that originally defined membership in the double-high e-ki-sáka vs. single-high $e$ $k i$-hánde reflexes of the PB LH class continues to play a role in the extension of the class. In (25) we tabulate the distribution of voicing categories for the medial consonant. The data indicate a strong bias for the e-ki-sáka class with double $\mathrm{H}$ to contain a medial voiceless consonant or voiced sonorant while the e-ki-hánde class contains a disproportionate number of ND. This difference is statistically significant: chi-square $=57.5, \mathrm{df}=1, \mathrm{p}=0.0001$.

$\begin{array}{llllll} & T & R & D & N D & \\ \text { e-kí-sáka } & 26 & 34 & 2 & 1 & \mathrm{~T}=\text { voiceless } \\ \text { e-ki-hánde } & 11 & 4 & 1 & 34 & \begin{array}{l}\mathrm{R}=\text { sonorant } \\ \mathrm{D}=\text { voiced obstruent } \\ \end{array} \\ & & & & & \mathrm{ND}=\text { prenasal voiced }\end{array}$

This finding suggests that the voicing or compensatory lengthening contributed by the medial consonant that originally defined membership in the two classes continues to play a role.

A similar finding holds for the split of the PB LL class to $/ 00 / e-k i-r y a ̈ t u$ 'shoe' vs. /0L/ e-ki-tsungu 'potato' (26). While the /0L/ class is much smaller, the low-tone favoring ND forms its largest subclass. A contingency table over the 
same $\mathrm{T}+\mathrm{N}$ vs. $\mathrm{D}+\mathrm{ND}$ yields a less robust but still significant difference: chi $\mathrm{sq}=$ 4.09, $\mathrm{df}=1, \mathrm{p}=0.043$.

(26)
$\begin{array}{cllll}T & R & D & N D\end{array}$
e-ki-ryätu $56 \quad 139 \quad 23 \quad 79$
e-ki-tsungu $22 \quad 12 \quad 7 \quad 24$
$\mathrm{T}=$ voiceless
$\mathrm{R}=$ sonorant
$\mathrm{D}=$ voiced
$\mathrm{ND}=$ prenasal voiced

Finally, the /L/ vs. /0/ contrast has also been extended to the monosyllables (27), dropping the tautomorphemic restriction in the postulated original state of (22). Once again both terms of the contrast have been extended so that the PB $\mathrm{H}$ class now has a final /L/ counterpart to the original /0/ and the PB L class now has a $/ \mathrm{L} /$ counterpart to the original $/ 0 /$. As with the disyllables, the extensions are smaller than the original classes.

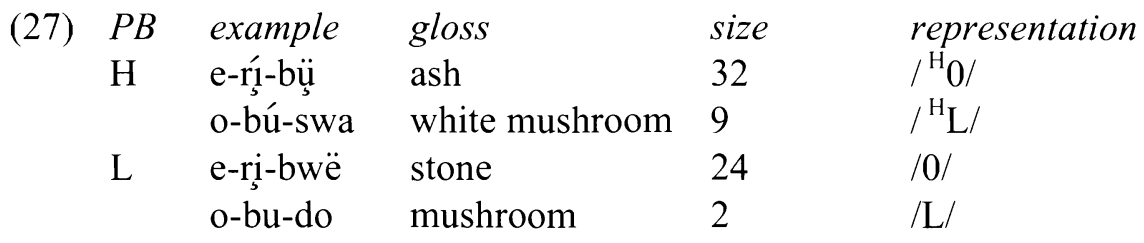

\section{Summary and Conclusions.}

This paper has traced the Proto-Bantu origin and the development of the six contrasting Kinande tonal classes of disyllabic nominal stems in (1) on the basis of two cognate sets. First, comparison with several closely related Lacustrine languages shows that the six classes originate from a HL, LH, LL contrast. Second, a deeper comparison with several Congolese languages suggests that the puzzling split of the HL class with respect to the presence or absence of a $\mathrm{H} \%$ boundary tone can actually be traced to a HH vs. HL contrast in Proto-Bantu, confirming a hypothesis in Meeussen (1976). We proposed a chronology of tonal changes leading to a reconstructed state with a ternary $\mathrm{H}$ vs. L vs. 0 contrast on the final syllable and a phonotactic constraint restricting the $\mathrm{L}$ tone to the context $\mathrm{H}$ The current Kinande lexicon has extended the ternary contrast by dropping the $\mathrm{H}$ restriction. Various lexical items have changed their tonal class affiliation based on alternative analyses of ambiguous phrase medial or phrase-final forms. 
The research reported here depends entirely on the availability of large and accurate lexicons such as Yukawa (1992), Kaji (1986, 1992, 2000, 2004), and Kagaya (2005). The construction of such lexical materials for a greater variety of languages is an urgent task for Bantu linguistics and will help to put the reconstructions by such pioneers as Greenberg, Guthrie, and Meeussen on a more solid footing.

\section{Appendices}

The first column is the assumed PB tonal reconstruction. The second grades the Kinande correspondence: a marks an expected reflex; b denotes an anomalous tonal or segmental correspondence. The next column shows the number of the Guthrie reconstruction followed by the actual form and then the reconstruction from Meeussen (1980). The Kinande forms are primarily from our consultant but were also checked with the Kavutirwaki (1978) and Mutaka \& Kavutirwaki (2006) lexicons. The Runyankore forms are taken from Kaji's (2004) lexicon and the Haya ones from Kaji (2000). Jita-U is from Downing's (1996) glossary based on the Ukerewe dialect and Jita-M is from Kagaya (2005) based on the Mrangi dialect. In appendix B, the Tembo data are taken from Kaji $(1986,1996)$ and the Luba data are from Yukawa (1992). For the Lingala column the forms labeled with $\mathrm{M}$ are Lomongo forms from Meeussen (1976) while the remaining data are Lingala words from Kaji (1992). 


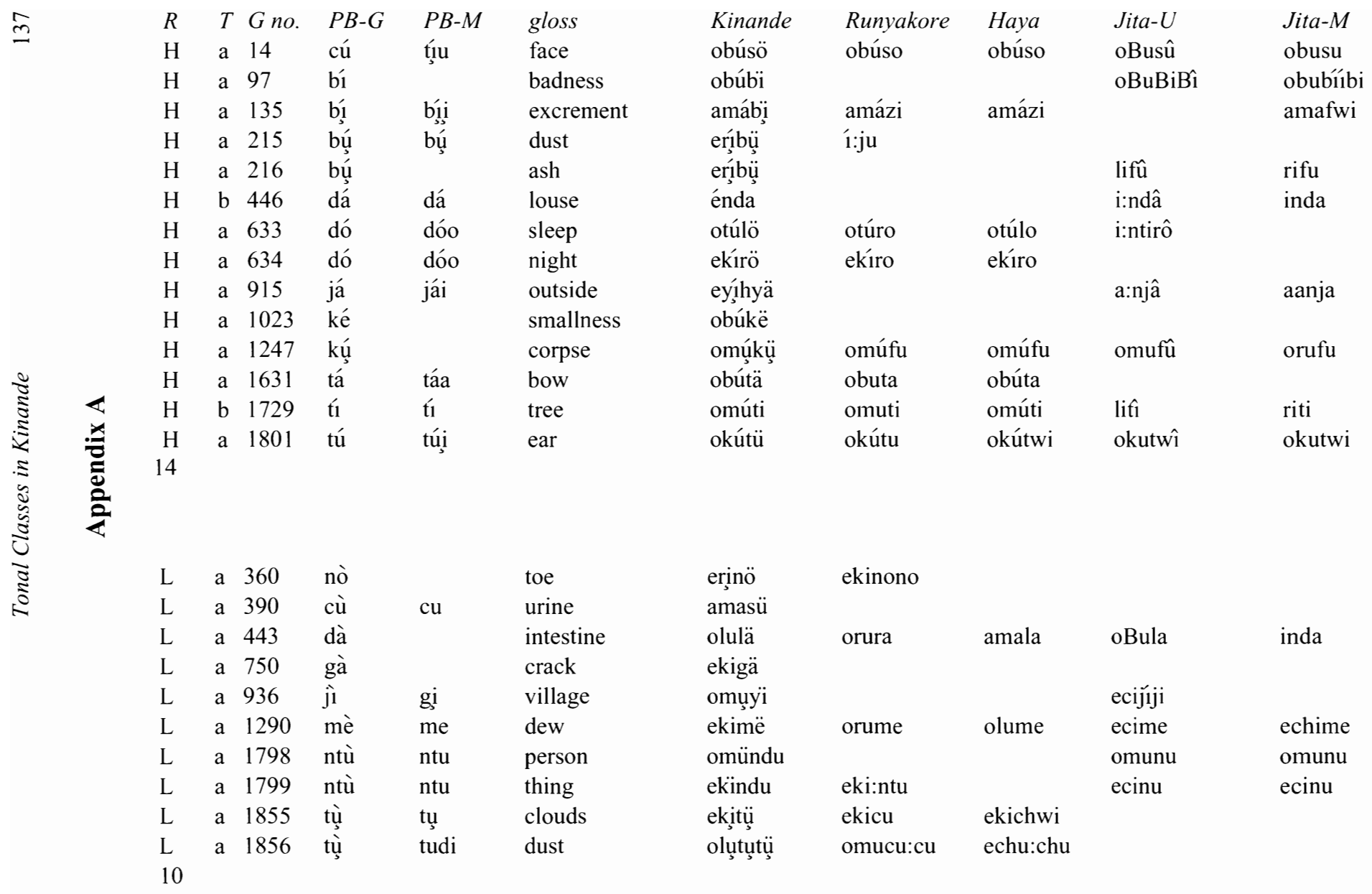




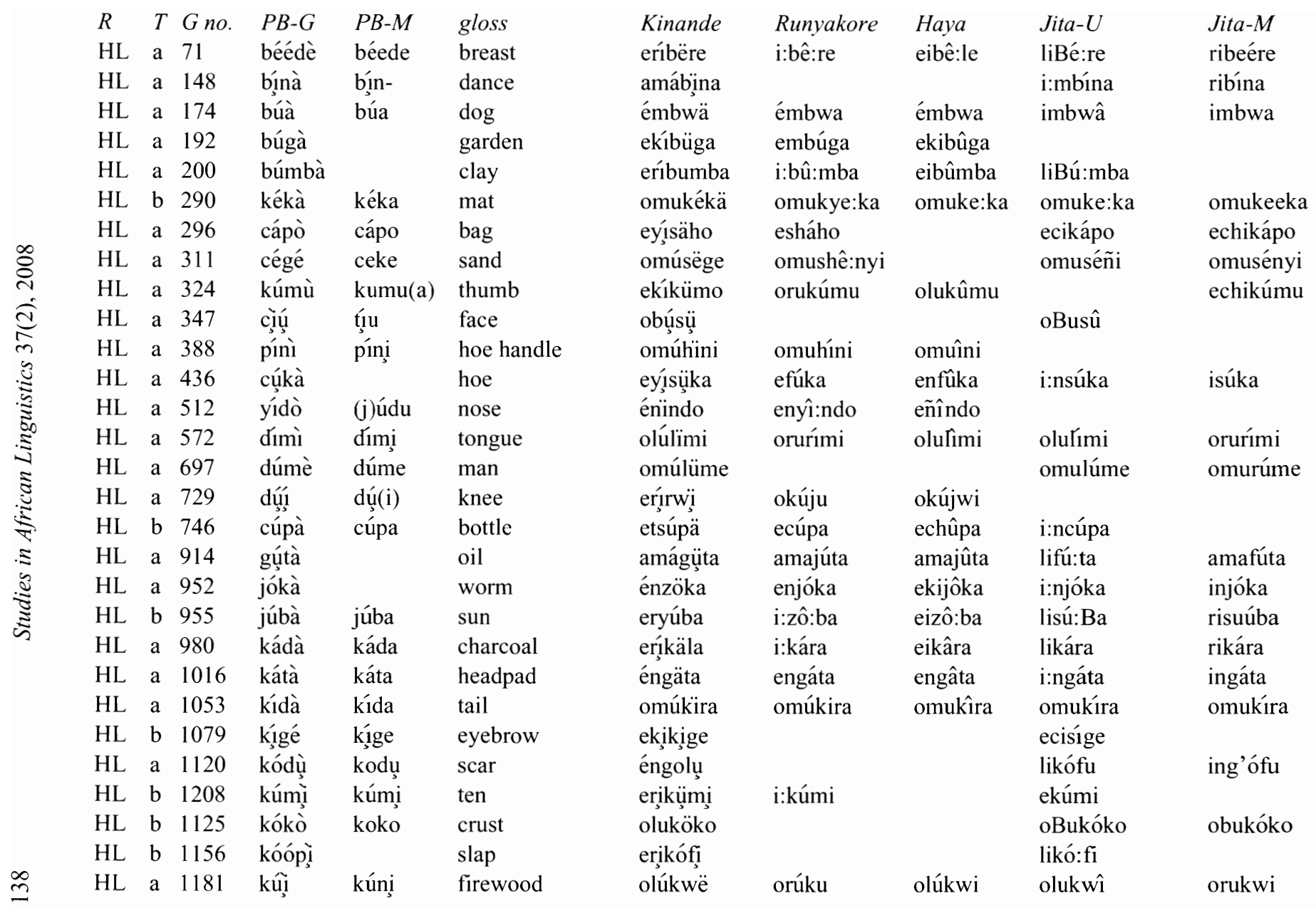




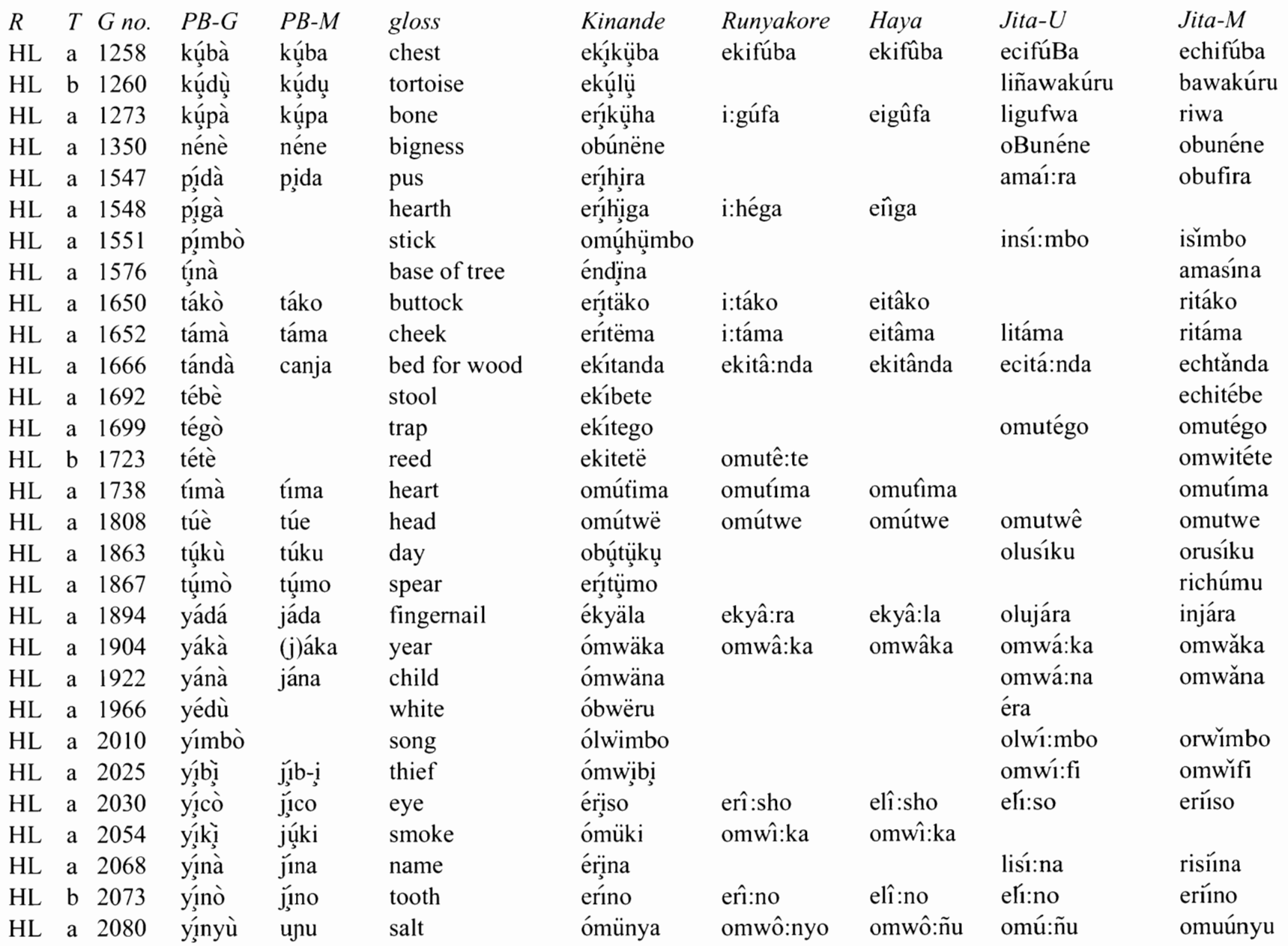




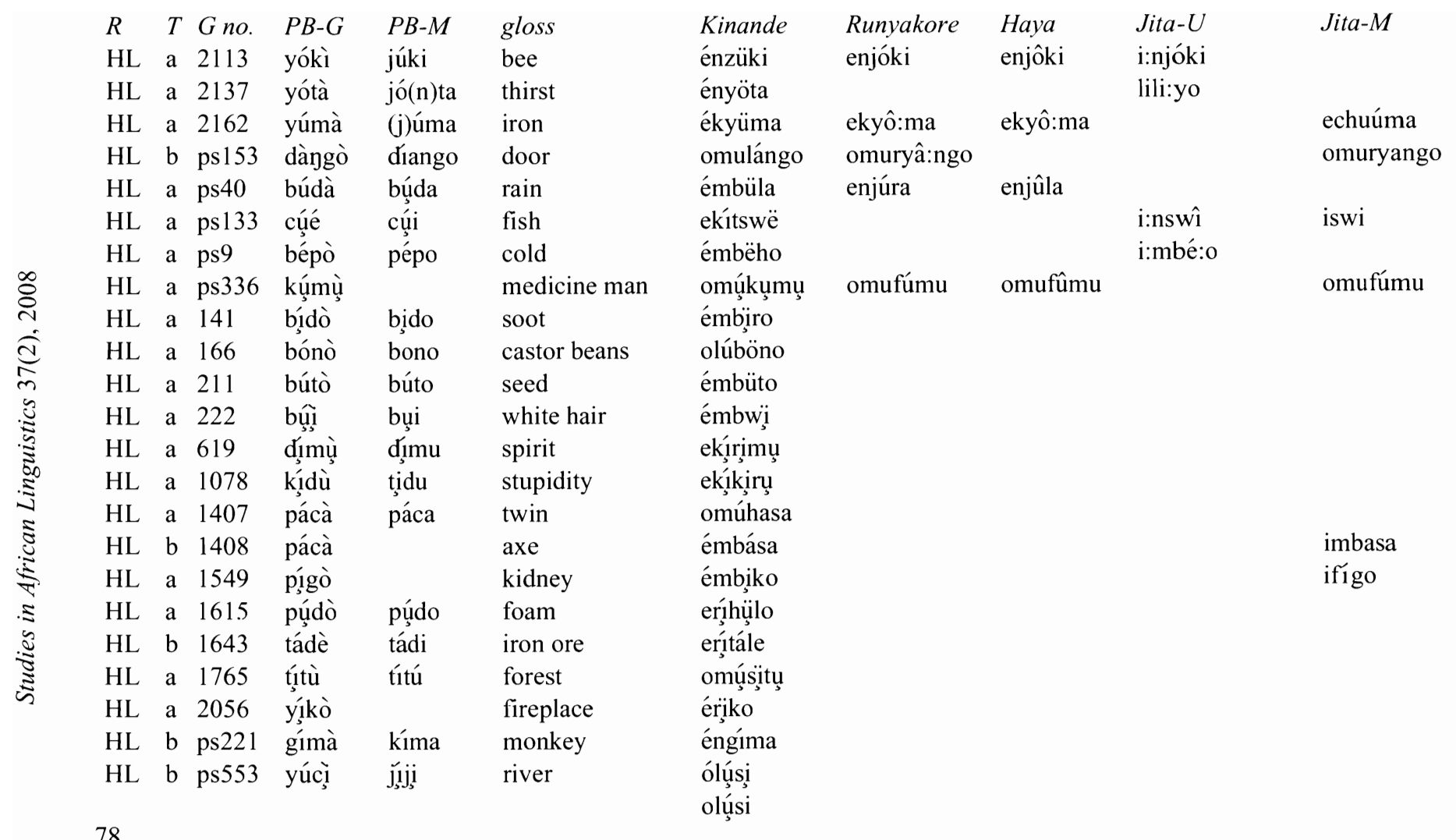




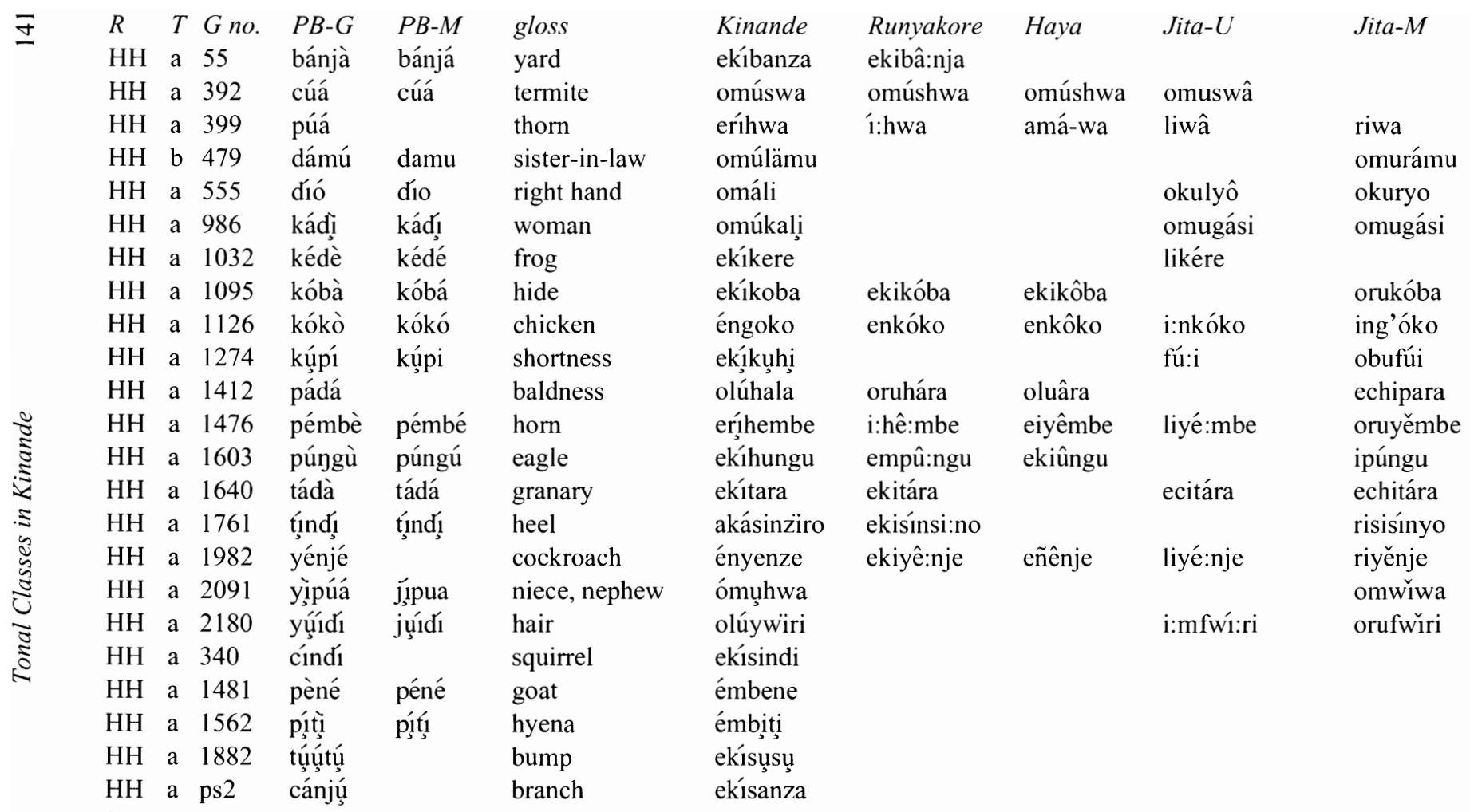




\section{R T G no. PB-G PB-M gloss \\ $\mathrm{LH} \quad \mathrm{b} 157$ bògó bogó buffalo}

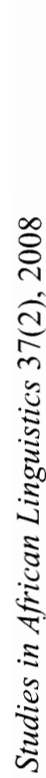

\begin{tabular}{|c|c|c|c|c|}
\hline LH & a 260 & càká & & bush \\
\hline LH & a 349 & ç̧cá & & vein \\
\hline LH & b 361 & nòní & (j)uní & bird \\
\hline LH & a 667 & dòygó & dongó & mud for building \\
\hline LH & a 744 & dụmbb́́ & & long rain \\
\hline LH & b 839 & gòd! & & bride \\
\hline LH & a 865 & gùàdı & kuadé & partridge \\
\hline $\mathrm{LH}$ & b 992 & kààká & kaka & grand-parent \\
\hline LH & a 1017 & kàté & & bread \\
\hline LH & b 1415 & pàdı́ & & ant \\
\hline LH & a 1450 & pàpá & papá & wing \\
\hline LH & a 1596 & pùká & puka & insect \\
\hline LH & b 1749 & țìkí & & stump \\
\hline LH & a 1749 & țikí & & stump \\
\hline LH & a 1948 & nyàț & & grass \\
\hline LH & b 1977 & yèndá & kenda & nine \\
\hline LH & a 2013 & yiná & jiná & hole in ground \\
\hline LH & a 2133 & yòngó & jongó & brain \\
\hline $\mathrm{LH}$ & b 2140 & yòyá & jojá & body hair \\
\hline LH & a 2167 & yùmbá & & room \\
\hline LH & a 2168 & yùmbá & (j)umbá & house \\
\hline LH & a $2173 a$ & nyùngú & & pot \\
\hline LH & b 788 & gàngá & & root \\
\hline LH & a 1436 & pàndé & & piece \\
\hline
\end{tabular}

\begin{tabular}{|c|c|c|c|c|}
\hline $\begin{array}{l}\text { Kinande } \\
\text { embögo } \\
\text { embógo } \\
\text { ébógo }\end{array}$ & $\begin{array}{l}\text { Runyakore } \\
\text { embogo }\end{array}$ & $\begin{array}{l}\text { Haya } \\
\text { embógo }\end{array}$ & $\begin{array}{l}\text { Jita-U } \\
\text { i:mbogô }\end{array}$ & $\begin{array}{l}\text { Jita-M } \\
\text { imbogo }\end{array}$ \\
\hline $\begin{array}{l}\text { eḱisáka } \\
\text { omúsísa }\end{array}$ & $\begin{array}{l}\text { ekishaka } \\
\text { omúsi }\end{array}$ & $\begin{array}{l}\text { ekisháka } \\
\text { omúsi }\end{array}$ & lisakâ & $\begin{array}{l}\text { risaka } \\
\text { omusiya }\end{array}$ \\
\hline $\begin{array}{l}\text { enyönyu } \\
\text { obudóngo } \\
\text { omụlúmbi }\end{array}$ & $\begin{array}{l}\text { ekinyonyi } \\
\text { obudô:ngo } \\
\text { omuju:mbi }\end{array}$ & $\begin{array}{l}\text { ekiñoñi } \\
\text { obudongo }\end{array}$ & i:ñoñi & inyonyi \\
\hline $\begin{array}{l}\text { omúgóle } \\
\text { engwáli }\end{array}$ & omugóre & omugóle & i:nkwa:rê & ing'wǎre \\
\hline $\begin{array}{l}\text { múkakä } \\
\text { omukáti } \\
\text { embäli }\end{array}$ & omuga:ti & omukâ:te & $\begin{array}{l}\text { káka } \\
\text { omuká:te } \\
\text { i:mpaji }\end{array}$ & $\begin{array}{l}\text { bakaáka } \\
\text { omukaáte }\end{array}$ \\
\hline ekípúps & iipapa & eipápa & liBaBâ & orubaba \\
\hline ekíhúka & ekihúka & ekiúka & & \\
\hline eḱ1şsiki & ekiŝ̂:nsi & ekisîbu & ecisiki & \\
\hline ekísíki & ekisí:ku & & & \\
\hline $\begin{array}{l}\text { obúnyátsi } \\
\text { omwënda }\end{array}$ & $\begin{array}{l}\text { orunyâ:nsi } \\
\text { omwenda }\end{array}$ & akañâ:si & liñási & rinyaási \\
\hline ekyụ́na & eki:na & eḱ́:na & & \\
\hline $\begin{array}{l}\text { obóngo } \\
\text { olwéya }\end{array}$ & $\begin{array}{l}\text { obwongko } \\
\text { orwo:ya }\end{array}$ & $\begin{array}{l}\text { obwôngo } \\
\text { omwó:ya }\end{array}$ & omwo:ngô & obwongo \\
\hline ekyúmba & & & ecú:mba & \\
\hline enyúmbä & & énju & i:ñú:mba & inyǔmba \\
\hline $\begin{array}{l}\text { enyúngu } \\
\text { erihánga }\end{array}$ & enyu:ngu & eñúngu & i:ñu:ngû & inyǔngu \\
\hline ekihánde & & & & echipande \\
\hline
\end{tabular}




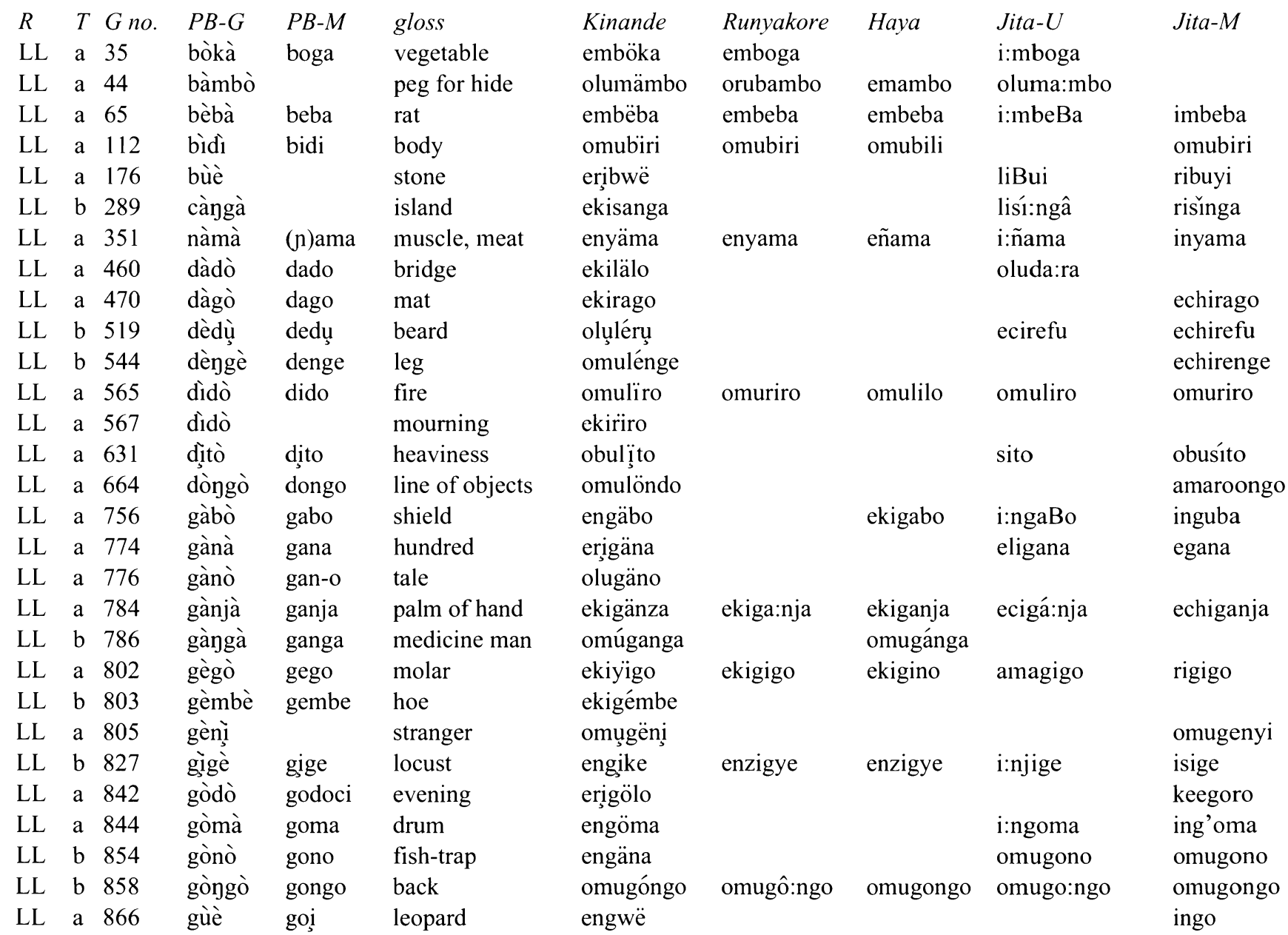




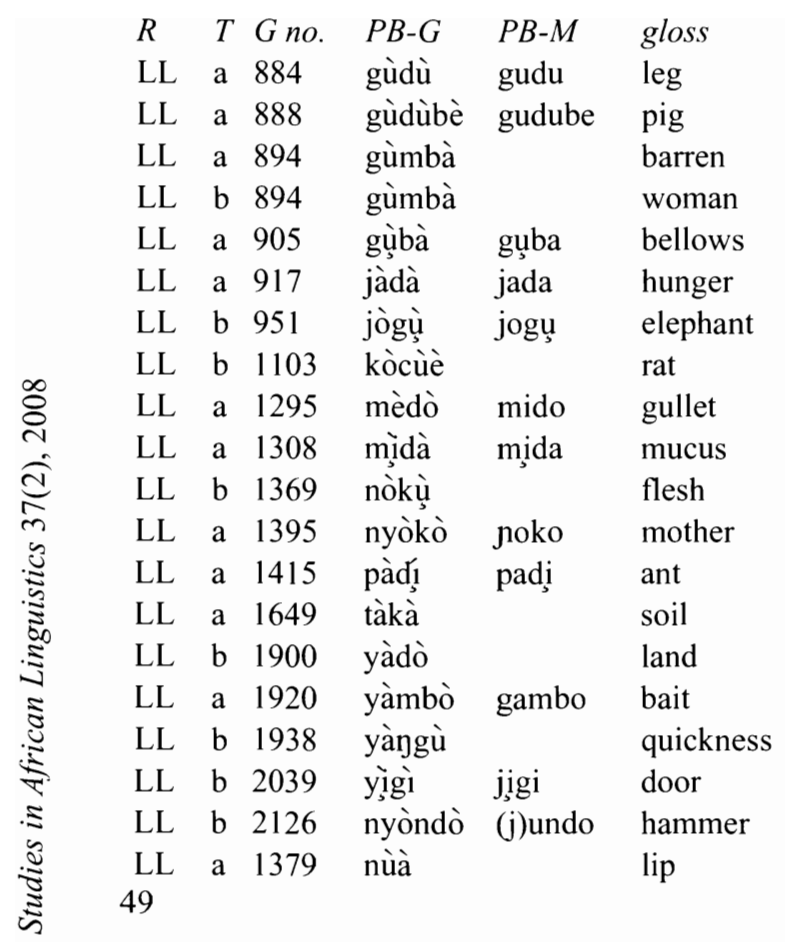

\begin{tabular}{|c|c|c|c|c|}
\hline $\begin{array}{l}\text { Kinande } \\
\text { okugülu } \\
\text { engulübe } \\
\text { omugümba } \\
\text { omugúmbä } \\
\text { omụgüba } \\
\text { enzäla }\end{array}$ & $\begin{array}{l}\text { Runyakore } \\
\text { okuguru }\end{array}$ & $\begin{array}{l}\text { Haya } \\
\text { okuguru }\end{array}$ & $\begin{array}{l}\text { Jita-U } \\
\text { okuguu } \\
\text { i:ngurúBe } \\
\text { omugu:- } \\
\text { mba } \\
\text { i:niara }\end{array}$ & $\begin{array}{l}\text { Jita-M } \\
\text { okuguru } \\
\text { ingurúbe } \\
\text { omugu- } \\
\text { mba }\end{array}$ \\
\hline $\begin{array}{l}\text { enzäla } \\
\text { enzógụ } \\
\text { engotși }\end{array}$ & $\begin{array}{l}\text { enjara } \\
\text { enjojo }\end{array}$ & $\begin{array}{l}\text { enjala } \\
\text { enjoju }\end{array}$ & $\begin{array}{l}\text { i:njara } \\
\text { i:njofu }\end{array}$ & injofu \\
\hline $\begin{array}{l}\text { omumëro } \\
\text { ebimịira } \\
\text { omụnyökus } \\
\text { nyöko }\end{array}$ & $\begin{array}{l}\text { omumIro } \\
\text { ebImIra }\end{array}$ & omumiro & limiro & echimiro \\
\hline $\begin{array}{l}\text { embäli } \\
\text { ekitäka } \\
\text { ekihäro }\end{array}$ & $\begin{array}{l}\text { empazi } \\
\text { i:taka }\end{array}$ & $\begin{array}{l}\text { obwa:zi } \\
\text { eitaka }\end{array}$ & $\begin{array}{l}\text { i:mpaji } \\
\text { litaka }\end{array}$ & \\
\hline $\begin{array}{l}\text { ekyämbo } \\
\text { obwängu }\end{array}$ & & & eca:mbo & obwambo \\
\hline $\begin{array}{l}\text { olüyi } \\
\text { enyóndo } \\
\text { omunywä }\end{array}$ & $\begin{array}{l}\text { orwi:gi } \\
\text { enyo:ndo } \\
\text { omunwa }\end{array}$ & $\begin{array}{l}\text { olw:igi } \\
\text { eñondo } \\
\text { omunwa }\end{array}$ & $\begin{array}{l}\text { olwi:gi } \\
\text { i:no:ndo }\end{array}$ & $\begin{array}{l}\text { orwigi } \\
\text { inundo } \\
\text { omunwa }\end{array}$ \\
\hline
\end{tabular}




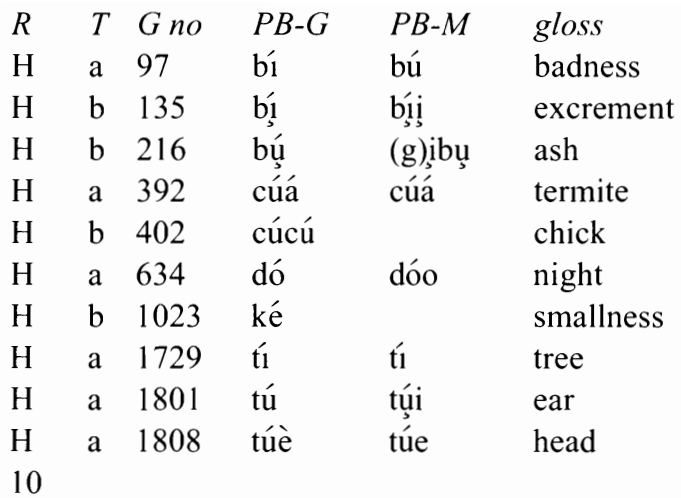

\begin{tabular}{|c|c|c|c|}
\hline Kinande & Tembo & Luba & Lingala \\
\hline obúbï & búbí & búbi & \\
\hline amábïi & másí & túufi & \\
\hline eŕ্blbü & lufúfú & bútu & \\
\hline $\begin{array}{c}\text { omúswa } \\
. .\end{array}$ & míhwáhwa & nswa & \\
\hline omusü & & cíkúkú & sósó \\
\hline ekírö & lúóloolo & dilolo & butú \\
\hline obúkë & múke & búkése & \\
\hline omúti & múć́ & múci & \\
\hline okútü & kútsú & dicu & litói \\
\hline omútwë & étswé & mútu & motó \\
\hline eribwë & & dibwé & \\
\hline ekimë & & dimé & \\
\hline ekisihü & cúfú & cífu & \\
\hline omündu & múndzú & múúntú & moto \\
\hline omúli & búre & múlé & \\
\hline
\end{tabular}

$\begin{array}{llllll}\text { HL a } & 71 & \text { béédè } & \text { béede } & \text { breast } \\ \text { HL } & \text { a } & 174 & \text { búà } & \text { búa } & \text { dog } \\ \text { HL } & \text { a } & 311 & \text { cégé } & \text { ceke } & \text { sand } \\ \text { HL } & \text { b } & 436 & \text { cúkà } & & \text { hoe } \\ \text { HL } & \text { a } & 479 & \text { dámú } & \text { damu } & \text { sister-in-law } \\ \text { HL a } & 512 & \text { ýdò } & \text { (j)údu } & \text { nose } \\ \text { HL a } & 572 & \text { dímì } & \text { dı́mi } & \text { tongue } \\ \text { HL a } & 697 & \text { dúmè } & \text { dúme } & \text { man } \\ \text { HL b } & 865 & \text { gùàdı } & \text { kuadé } & \text { partridge } \\ \text { HL b } & 914 & \text { gútà } & & \text { oil } \\ \text { HL a } & 952 & \text { iókà } & \text { ióka } & \text { snake }\end{array}$

\begin{tabular}{|c|c|c|c|}
\hline eríbëre & éberé & dibeelé & libéle \\
\hline émbwä & ḿbwá & mbwá & mbwá \\
\hline omúsëge & músheé & lúsééngá & \\
\hline eýśsüka & fuká & nkasú & \\
\hline omúlämu & múlamú & & \\
\hline énïndo & & dyúulú & zólo \\
\hline olúlïmi & lúlimí & lúdimí & lolémo \\
\hline omúlüme & múlumé & múlumé & \\
\hline engwáli & & nkwáadi & \\
\hline amágüta & máfutá & mafúta & mafúta \\
\hline énzöka & ńzoká & nyoká & nyóka \\
\hline
\end{tabular}




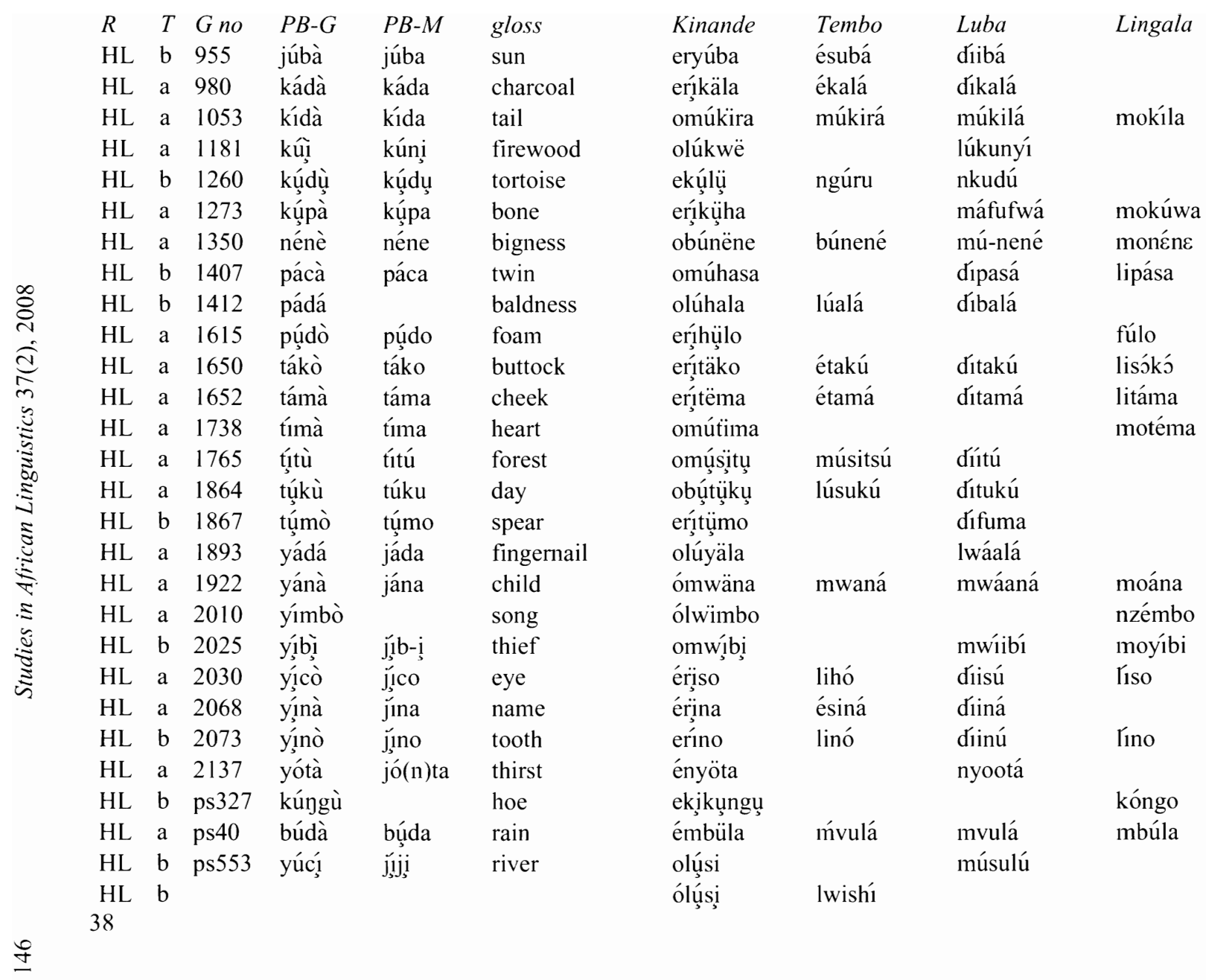




\begin{tabular}{|c|c|c|c|c|c|c|c|c|c|}
\hline \multirow{12}{*}{ 呑 } & $T$ & $G$ no & $P B-G$ & \multirow{2}{*}{$\begin{array}{l}P B-M \\
\text { bánjá }\end{array}$} & \multirow{3}{*}{$\begin{array}{l}\text { gloss } \\
\text { courtyard } \\
\text { clay }\end{array}$} & \multirow{3}{*}{$\begin{array}{l}\text { Kinande } \\
\text { ekíbanza } \\
\text { eríbumba }\end{array}$} & \multirow{2}{*}{$\begin{array}{l}\text { Tembo } \\
\text { cíbanja }\end{array}$} & \multirow{3}{*}{$\begin{array}{l}\text { Luba } \\
\text { banza }(\mathrm{M}) \\
\text { lúpeemba }\end{array}$} & \multirow[t]{3}{*}{ Lingala } \\
\hline & $\mathrm{a}$ & 55 & bánjà & & & & & & \\
\hline & b & 200 & búmbà & & & & & & \\
\hline & $\mathrm{a}$ & 340 & ćindi & kindi & squirrel & eḱ́sindi & & nshiindi & \\
\hline & $\mathrm{a}$ & 986 & kádì & kád, & woman & omúkali & múkasi & múkaji & moásí \\
\hline & $\mathrm{a}$ & 1032 & kédè & kédé & frog & ekikere & cíkere & & \\
\hline & $\mathrm{a}$ & 1095 & kóbà & kóbá & skin & éngoba & cíkoba & dikoba & \\
\hline & $\mathrm{a}$ & 1126 & kókò & kókó & chicken & éngoko & ńgoko & cíkúkú & kókó (M) \\
\hline & a & 1197 & kúdù & kúdú & oldness & obúkulu & múkulu & búkulúúmpé & kúlú (M) \\
\hline & $\mathrm{a}$ & 1274 & kứpí & kứpi & shortness & ekślkushi & & bwíipi & \\
\hline & $\mathrm{a}$ & 1547 & pídà & pida & pus & ersíhira & másira & túfina & mayíná \\
\hline & $\mathrm{a}$ & 1603 & púngù & púngú & eagle & ekíhungu & & & púngú $(\mathrm{M})$ \\
\hline \multirow{6}{*}{ 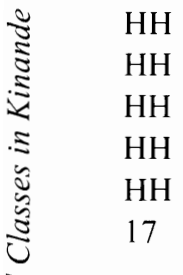 } & $\mathrm{a}$ & 1874 & túmbí & & chair & ekítumbi & ć́fumbi & & \\
\hline & b & 1952 & yáyù & jáju & yawn & émyaya & & mwáau & \\
\hline & $\mathrm{a}$ & ps336 & kứmụ́ & & witchdoctor & omụ́ku̧ıụ & & fumu (M) & \\
\hline & $\mathrm{b}$ & & & & belt & omukábä & ćkábá & múkaba & \\
\hline & $\mathrm{a}$ & & & & beer & óbwabụ & mafu & & \\
\hline & & & & & & & & & \\
\hline \multirow{10}{*}{ స్త } & a & 349 & ç̧cá & & vein & omứśísa & & & mosisá \\
\hline & $\mathrm{b}$ & 1450 & pàpá & baba & wing & ekispụ́pa & & dıpwáapwá & lipapú \\
\hline & $\mathrm{a}$ & 1450 & pàpá & papu & lungs & ekíháha & ciáa & & \\
\hline & b & 1630 & tá & táa & war & efistä & bitá & mvíta & \\
\hline & b & 1686 & tààtá & taatá & father & abótatä & bátatá & táátu & \\
\hline & $\mathrm{a}$ & 1895 & jàdı́ & jadı & young girl & omwáli & mwályi & & \\
\hline & $\mathrm{b}$ & 2013 & yiná & jiná & hole & ekyúna & mwíná & ć́iná & \\
\hline & b & 2133 & yòngó & jongó & brain & obóngo & bóngó & bóonko & \\
\hline & $\mathrm{a}$ & 2140 & jòjá & jojá & body hair & olwéya & lóya & bóoya & \\
\hline & $\mathrm{a}$ & 2168 & yùmbá & (j)umbá & house & enyúmbä & nyúmba & & \\
\hline
\end{tabular}




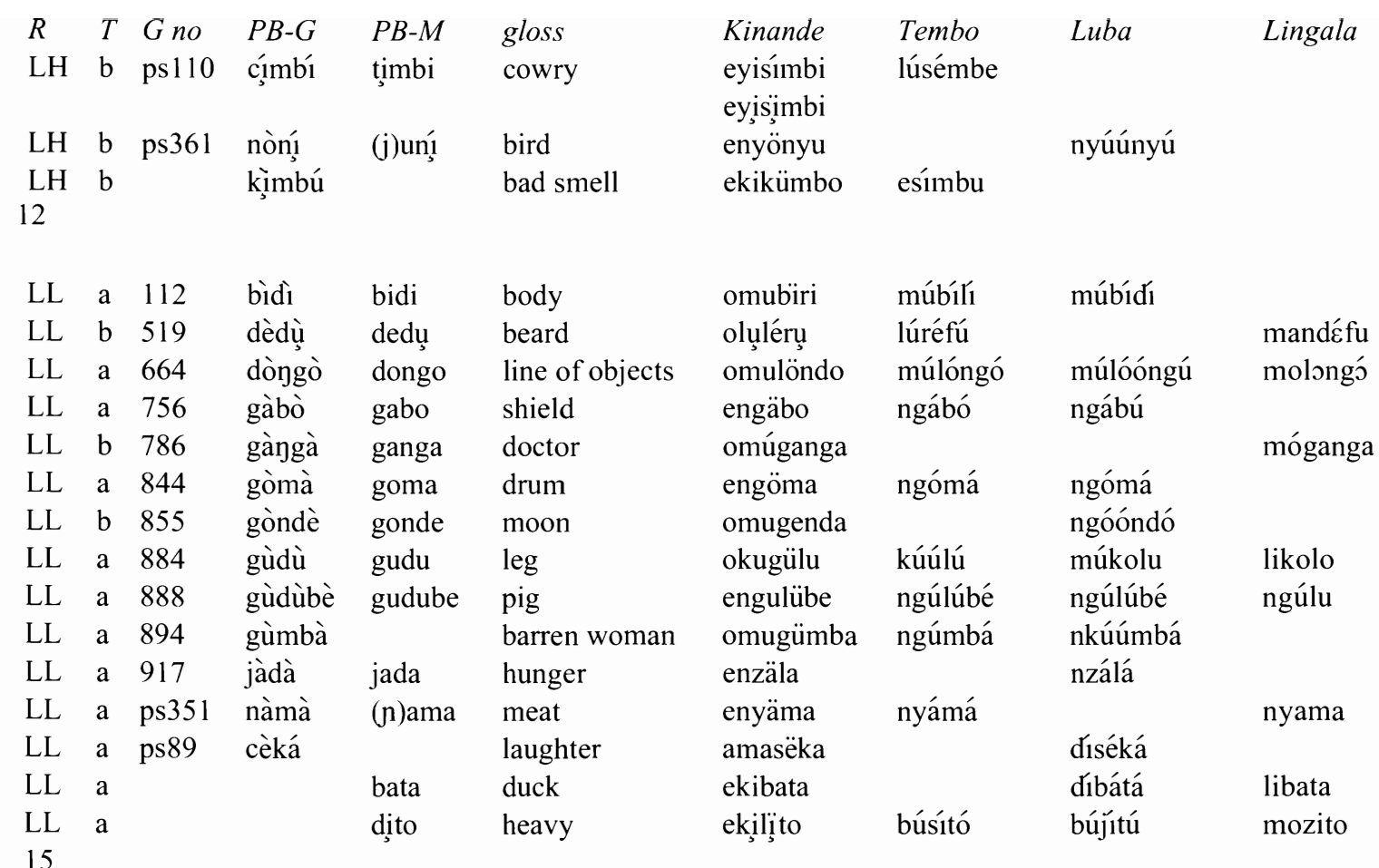




\section{REFERENCES}

Albright, Adam \& Bruce Hayes. 2003. "Rules vs. analogy in English past tenses: a computational/experimental study". Cognition 90: 119-61.

Cassimjee, Farida \& Charles Kisseberth. 1998. "Optimal domains theory and Bantu tonology". Theoretical Aspects of Bantu Tone, ed. by Larry Hyman \& Charles Kisseberth. Stanford University: Center for the Study of Language and Information. Pp. 33-132.

Clements, George N. 2003. "Feature economy in sound systems". Phonology 20: 287-333.

Clements, George N. \& John Goldsmith. 1984. "Introduction". Autosegmental Studies in Bantu Tone. Dordrecht: Foris Publications, Pp. 1-17.

Downing, Laura. 1996. The Tonal Phonology of Jita. München: Lincom Europa.

Downing, Laura. 2009. "On pitch lowering not linked to voicing: Nguni and Shona group depressors". Language Sciences 31: 179-98.

Goldsmith, John \& Firmard Sabimana. 1986. "The Kirundi verb". Modèles en tonologie, ed. by Francis Jouannet. Paris: Editions du CNRS. Pp. 19- 62.

Greenberg, Joseph. 1948. "The tonal system of Proto-Bantu". Word 4: 196-208.

Guthrie, Malcolm. 1967-1971. Comparative Bantu (4 vols). London: Gregg.

Hayes, Bruce \& Colin Wilson. 2008. "A maximum entropy model of phonotactics and phonotactic learning". Linguistic Inquiry 39: 379-440.

Hyman, Larry. 1990. "Boundary tonology and the prosodic hierarchy". The Phonology-Syntax Connection, ed. by Sharon Inkelas \& Draga Zec. Chicago: University of Chicago Press. Pp. 109-25.

Hyman, Larry \& Ernest Rugwa Byarushengo. 1984. "A model of Haya tonology". Autosegmental Studies in Bantu Tone, ed. by George N. Clements \& John Goldsmith. Dordrecht: Foris Publications. Pp. 53- 103. 
Hyman, Larry \& Nzama Valinande. 1985. "Globality in the Kinande tone system". African Linguistics: Essays in Memory of M.W.K. Semikenke, ed. by Didier Goyvearts. Amsterdam: John Benjamins. Pp. 239-60.

Jones, Patrick. 2007. "Excel file of Kinande verbal and nominal stems based on Kavutirwaki's 1978 dictionary". MIT ms.

Kagaya, Ryohei. 2005. A Jita Vocabulary. Asian and African Lexicon no. 47. Tokyo: Institute for the Study of Languages and Cultures of Asia and Africa, Tokyo University of Foreign Studies.

Kaji, Shigeki. 1986. Lexique Tembo. Asian and African Lexicon no. 5. Tokyo: Institute for the Study of Languages and Cultures of Asia and Africa, Tokyo University of Foreign Studies.

Kaji, Shigeki. 1992. Vocabulaire lingala classifié. African Languages and Ethnography no. 26. Tokyo: Institute for the Study of Languages and Cultures of Asia and Africa, Tokyo University of Foreign Studies.

Kaji, Shigeki. 1996. "Tonal reversal in Tembo (Bantu J. 57)". Journal of African Languages and Linguistics 17: 1-26.

Kaji, Shigeki. 2000. A Haya Vocabulary. Asian and African Lexicon no. 37. Tokyo: Institute for the Study of Languages and Cultures of Asia and Africa, Tokyo University of Foreign Studies.

Kaji, Shigeki. 2004. A Runyankore Vocabulary. Asian and Africa Lexicon no. 44. Tokyo: Institute for the Study of Languages and Cultures of Asia and Africa, Tokyo University of Foreign Studies.

Kavutirwaki, Kambale. 1978. Lexique nande-français, français-nande. Kinshasa: Editions du Sécrétariat Générale de l'Episcopat du Zaire.

Kenstowicz, Michael \& Charles Kisseberth. 1990. "Chizigula tonology: the word and beyond". The Phonology-Syntax Connection ed. by Sharon Inkelas \& Draga Zec. Chicago: University of Chicago Press. Pp. 163-94.

Kisseberth, Charles. 1984. "Digo tonology". Autosegmental Studies in Bantu Tone, ed. by George N. Clements \& John Goldsmith. Dordrecht: Foris Publications. Pp. 105-82. 
Meeussen, A. E. 1976. "Notes on tone in Bantu nominal stems". African Languages 2: $60-70$.

Meeussen, A. E. 1980. Bantu Lexical Reconstructions. Archief voor Antropologie 27, Tervuren: Koninklijk Museum voor Midden-Afrika.

Mutaka, Ngessimo. 1994. The Lexical Phonology of Kinande. München: Lincom Europa.

Muataka, Ngessimo \& Kambale Kavutirwaki. 2006. Kinande-English Dictionary. Tervuren: Koninklijk Museum voor Midden-Afrika.

Odden, David. 1996. The Phonology and Morphology of Kimatumbi. Oxford: Oxford University Press.

Philippson, Gerard. 1998. "*HH and *HL tone patterns in Bemba and the Bemba tone system". Bantu Historical Linguistics, ed. by Jean-Marie Hombert \& Larry Hyman. Stanford University: Center for the Study of Language and Information. Pp. 395-409.

Poletto, Robert. 1998. Topics in Runyankore Phonology. Columbus: Ohio State University, Ph.D. dissertation.

Xu, Yi. 2007. TimenormalizeF0.praat. 2.6.6.

Yukawa, Yasutoshi. 1992. A Classified Vocabulary of the Luba Language. Bantu Vocabulary Series 7. Tokyo: Institute for the Study of Languages and Cultures of Asia and Africa, Tokyo University of Foreign Studies.

MIT Linguistics and Philosophy

77 Massachusetts Avenue, 32-D808

Cambridge, MA 02139

kenstow@mit.edu [received April 25, 2009, accepted Aug 9 2009] 
